Article

\title{
The Function of Mitochondrial Calcium Uniporter at the Whole-Cell and Single Mitochondrion Levels in WT, MICU1 KO, and MICU2 KO Cells
}

\author{
Syed Islamuddin Shah and Ghanim Ullah *(D) \\ Department of Physics, University of South Florida, Tampa, FL 33647, USA; syedislamudd@mail.usf.edu \\ * Correspondence: gullah@usf.edu; Tel.: +1-813-974-0698
}

Received: 14 May 2020; Accepted: 16 June 2020; Published: 22 June 2020

\begin{abstract}
Mitochondrial $\mathrm{Ca}^{2+}\left(\left[\mathrm{Ca}^{2+}\right]_{\mathrm{M}}\right)$ uptake through its $\mathrm{Ca}^{2+}$ uniporter $(\mathrm{MCU})$ is central to many cell functions such as bioenergetics, spatiotemporal organization of $\mathrm{Ca}^{2+}$ signals, and apoptosis. MCU activity is regulated by several intrinsic proteins including MICU1, MICU2, and EMRE. While significant details about the role of MICU1, MICU2, and EMRE in MCU function have emerged recently, a key challenge for the future experiments is to investigate how these regulatory proteins modulate mitochondrial $\mathrm{Ca}^{2+}$ influx through $\mathrm{MCU}$ in intact cells under pathophysiological conditions. This is further complicated by the fact that several variables affecting MCU function change dynamically as cell functions. To overcome this void, we develop a data-driven model that closely replicates the behavior of MCU under a wide range of cytosolic $\mathrm{Ca}^{2+}\left(\left[\mathrm{Ca}^{2+}\right]_{\mathrm{C}}\right),\left[\mathrm{Ca}^{2+}\right]_{\mathrm{M}}$, and mitochondrial membrane potential values in WT, MICU1 knockout (KO), and MICU2 KO cells at the single mitochondrion and whole-cell levels. The model is extended to investigate how MICU1 or MICU2 KO affect mitochondrial function. Moreover, we show how $\mathrm{Ca}^{2+}$ buffering proteins, the separation between mitochondrion and $\mathrm{Ca}^{2+}$-releasing stores, and the duration of opening of $\mathrm{Ca}^{2+}$-releasing channels affect mitochondrial function under different conditions. Finally, we demonstrate an easy extension of the model to single channel function of MCU.
\end{abstract}

Keywords: mitochondrial $\mathrm{Ca}^{2+}$ uptake; mitochondrial $\mathrm{Ca}^{2+}$ uniporter; MICU1; MICU2; EMRE; $\mathrm{Ca}^{2+}$ overload

\section{Introduction}

Mitochondrial $\mathrm{Ca}^{2+}$ uptake plays a central role in cell metabolism, signaling, and survival [1-3]. $\mathrm{Ca}^{2+}$ entry into the matrix is mediated by the $\mathrm{Ca}^{2+}$ uniporter-channel complex with a high selectivity for $\mathrm{Ca}^{2+}$ and large carrying capacity [4-8]. This complex consists of mitochondrial $\mathrm{Ca}^{2+}$ uniporter (MCU), which constitutes the pore-forming subunit of the channel $[5,9]$. MCU interacts with several intrinsic proteins that regulate its activity. These include mitochondrial $\mathrm{Ca}^{2+}$ uptake protein 1 (MICU1) [10], MICU2 [11-13], MICU3 [14], MCU regulator 1 [15], and essential MCU regulator protein (EMRE) [16-18]. While MICU3 is largely restricted to brain, MICU1 and MICU2 are widely expressed and play major roles in mitochondrial $\mathrm{Ca}^{2+}$ uptake in most human cells $[13,14]$. Similarly, EMRE has been shown to play a key role in the regulation of $\mathrm{MCU}$ activity in the mitochondrial $\mathrm{Ca}^{2+}$ concentration $\left(\left[\mathrm{Ca}^{2+}\right]_{\mathrm{M}}\right)$-dependent manner [17-19].

Significant information about the role of regulatory proteins described above in the function of MCU has emerged over the last few years [10-15,18-22]. In particular, MICU1 has been shown to mediate the observed suppression of MCU activity in the low cytosolic $\mathrm{Ca}^{2+}$ concentration $\left(\left[\mathrm{Ca}^{2+}\right]_{\mathrm{C}}\right)$ regime, called "gatekeeping" [12]. This gatekeeping of MCU activity is relieved when $\left[\mathrm{Ca}^{2+}\right]_{C}$ reaches approximately $1.3 \mu \mathrm{M}$. Below this critical concentration, $\mathrm{Ca}^{2+}$ uptake through $\mathrm{MCU}$ is essentially 
negligible. MICU1 is also responsible for the observed highly cooperative activation of MCU activity where the gatekeeping is cooperatively relieved when $\left[\mathrm{Ca}^{2+}\right]_{\mathrm{C}}$ exceeds $1.3 \mu \mathrm{M}[12]$ (Figure 1B). Similarly, MICU2 interacts with MICU1 to increase the $\left[\mathrm{Ca}^{2+}\right]_{C}$ threshold for the gatekeeping and reduce the gain of cooperative activation of MCU activity [12] (Figure 1B). EMRE, on the other hand, plays a role in regulating MCU activity on the matrix side of the inner mitochondrial membrane (IMM) such that the uptake is minimum when $\left[\mathrm{Ca}^{2+}\right]_{\mathrm{M}}$ is approximately $400 \mathrm{nM}[18,19]$. Thus, MCU exhibits a biphasic behavior where the current through the channel increases as $\left[\mathrm{Ca}^{2+}\right]_{\mathrm{M}}$ drops below or rises above $400 \mathrm{nM}$ (Figure 1C). Furthermore, MICU1 and MICU2 are required for the matrix $\mathrm{Ca}^{2+}$ regulation of MCU such that the inhibition at the intermediate $\left[\mathrm{Ca}^{2+}\right]_{\mathrm{M}}$ disappears when either one of the two proteins are knocked out [19].

(A)

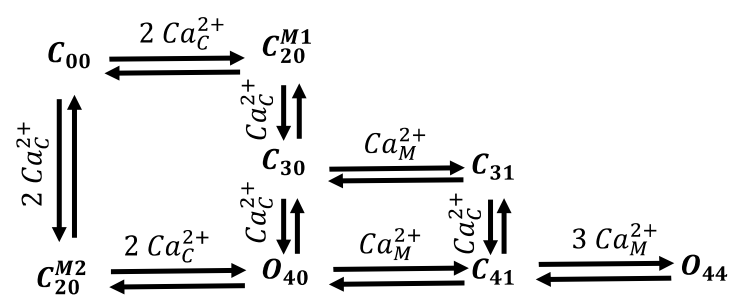

(C)

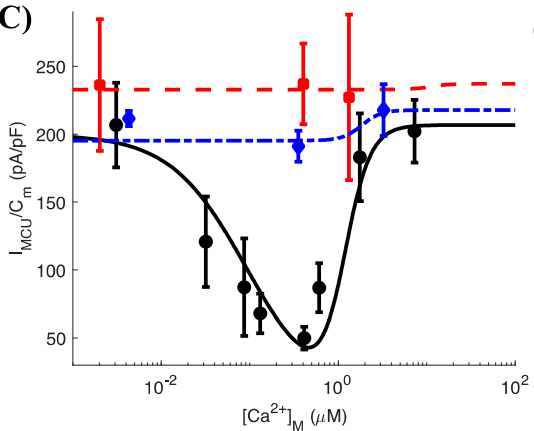

(B)

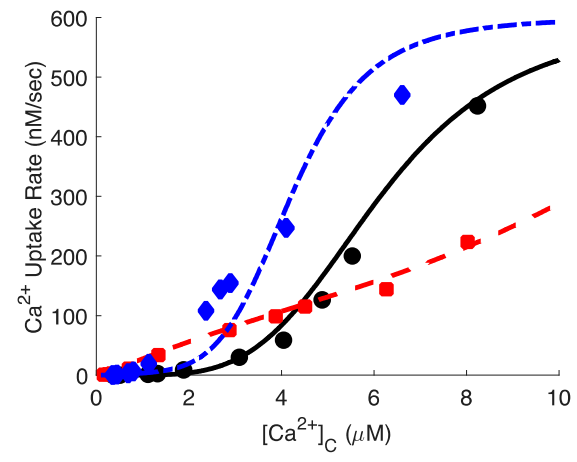

(E)
(D)

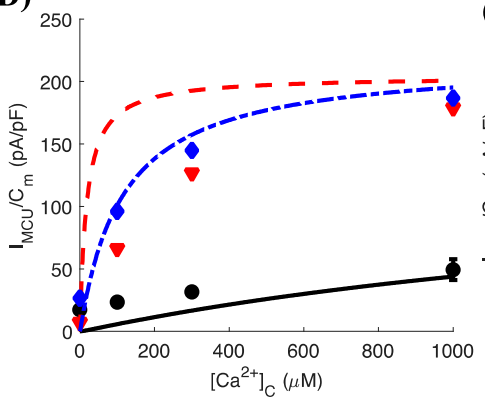

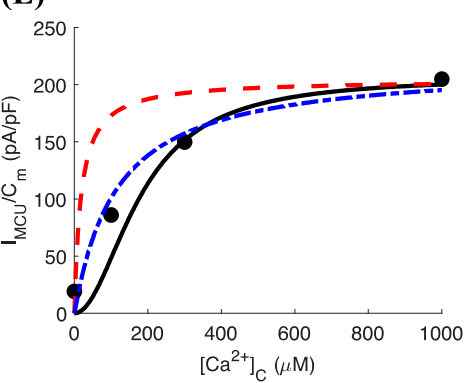

Figure 1. Scheme and fit to the experimental data of the MCU model. (A) The model consists of six close states $\left(C_{X Y}\right)$ and two open $\left(O_{X Y}\right)$ states. The subscripts $X$ and $Y$ represent the number of $\mathrm{Ca}^{2+}$ bound to domains of MCU on the cytosolic and matrix sides of the IMM. The superscripts M1 or M2 on the two close states with $2 \mathrm{Ca}^{2+}$ bound on the cytosolic side indicate whether the ions are bound to the MICU1 EF hands or MICU2 EF hands. The channel has $2 \mathrm{Ca}^{2+}$ bound to MICU1 and one $\mathrm{Ca}^{2+}$ bound to MICU2 on cytosolic side in state $C_{3 \gamma}$. (B) $\mathrm{Ca}^{2+}$ uptake rate as a function of $\left[\mathrm{Ca}^{2+}\right]_{\mathrm{C}}$ in WT (spheres, solid line), MICU1 KO (squares, dashed line), and MICU2 KO (diamonds, dashed-dotted line) cells. (C) MCU current density $\left(\mathrm{I}_{\mathrm{MCU}} / \mathrm{C}_{\mathrm{m}}\right)$ as a function of $\left[\mathrm{Ca}^{2+}\right]_{\mathrm{M}}$ at $\left[\mathrm{Ca}^{2+}\right]_{\mathrm{C}}=1 \mathrm{mM},(\mathbf{D})$ as a function of $\left[\mathrm{Ca}^{2+}\right]_{\mathrm{C}}$ at $\left[\mathrm{Ca}^{2+}\right]_{\mathrm{M}}=0.4 \mu \mathrm{M}$, and $(\mathrm{E})$ as a function of $\left[\mathrm{Ca}^{2+}\right]_{\mathrm{C}}$ at $\left[\mathrm{Ca}^{2+}\right]_{\mathrm{M}}=0 \mu \mathrm{M}$ in WT, MICU1 KO, and MICU2 KO mitoplasts. The lines and symbols use the same convention as in panel (B). Triangles in panel (D) represent MICU1 KD mitoplasts. Symbols and lines in panels (B-E) represent observed and theoretical values, respectively. Experimental data shown for comparison is from [12] (B) and [19] (C-E).

Despite this wealth of information, many key issues about the activity of MCU and the role of different regulatory proteins in mitochondrial function remain unresolved and are beyond the scope of current experimental techniques. For instance, while experimental tools can be used to study the activity of MCU or how it is affected by a given regulatory protein at discrete fixed values of one or two variables, several variables affecting mitochondrial $\mathrm{Ca}^{2+}$ uptake in real cells vary continuously in mutually dependent manner. Furthermore, the observations about MCU activity are based on experiments performed at different spatiotemporal scales ranging from patch clamp electrophysiology 
of single $\mathrm{Ca}^{2+}$ uniporter channels and individual mitoplasts to the imaging of $\mathrm{Ca}^{2+}$ uptake at the cell culture level using fluorescence microscopy (e.g., see $[6,11,12,19])$. Linking these observations at different scales is key to understanding the role of $\mathrm{Ca}^{2+}$ in mitochondrial and cell function. For example, while significant data about mitochondria-dependent variables such as ATP and reactive oxygen species as a function of $\mathrm{Ca}^{2+}$ at the whole-cell or cell culture levels exists, mitochondrial $\mathrm{Ca}^{2+}$ uptake and function are mainly regulated by local $\mathrm{Ca}^{2+}$ concentration in a few tens of nanometers wide microdomain formed by the close apposition of plasma membrane or intracellular organelles with individual mitochondrion [23-26]. These and a range of other observations underscore the importance of incorporating the key observations about the role of regulatory proteins in the function of MCU in a comprehensive computational framework.

The importance of a computational model incorporating the role of regulatory proteins in the function of MCU is further highlighted by the role of these proteins in various pathologies. For example, the human loss-of-function mutations in MICU1 results in mitochondrial $\mathrm{Ca}^{2+}$ overload, impaired bioenergetics, and mitochondrial fragmentation [27]. These MICU1-induced defects in mitochondrial $\mathrm{Ca}^{2+}$ signaling and function are believed to result in early-onset neuromuscular weakness, impaired cognition, and extrapyramidal motor disorder [27-29]. A whole-body knockout of MICU1 has also been reported to result in perinatal lethality in mouse models [30,31]. In addition, the expression levels of EMRE were also altered in patients with MICU1 mutations compared to controls [27]. Recently, it has been shown that mutations in mitochondrial m-AAA proteases associated with spinocerebellar ataxia and hereditary spastic paraplegia inflict their cytotoxicity by affecting the biogenesis of EMRE. This leads to the accumulation of active MCU-EMRE channels lacking gatekeeping, which facilitates mitochondrial $\mathrm{Ca}^{2+}$ overload, opening of mitochondrial permeability transition pore, and neurodegeneration [32].

In this paper, we (1) develop a comprehensive data-driven model that reproduces the key observations about the function of MCU under a range of $\left[\mathrm{Ca}^{2+}\right]_{\mathrm{C}},\left[\mathrm{Ca}^{2+}\right]_{\mathrm{M}}$, and mitochondrial membrane potential (MMP or $\Delta \psi$ ) values in WT, MICU1 KO, and MICU2 KO cells; (2) combine the observations at the cell culture (whole-cell) and single mitoplasts levels into a single mathematical framework; (3) investigate how the $\mathrm{Ca}^{2+}$ signaling in the microdomain between the endoplasmic reticulum (ER) and mitochondrion compares in WT, MICU1 KO, and MICU2 KO mitoplasts by modeling the interaction between the ER-bound inositol 1,4,5-trisphosphate $\left(\mathrm{IP}_{3}\right)$ receptor $\left(\mathrm{IP}_{3} \mathrm{R}\right)$ channel and MCU; (4) how does MICU1 or MICU2 KO affect mitochondrial function both in terms of $\mathrm{Ca}^{2+}$ uptake and ATP production; and (5) investigate the effect of $\mathrm{Ca}^{2+}$ buffers, width of the microdomain, and open duration of $\mathrm{IP}_{3} \mathrm{R}$ on mitochondrial $\mathrm{Ca}^{2+}$ uptake and ATP production in WT, MICU1 KO, and MICU2 KO cells.

\section{Materials and Methods}

The experimental data used in this paper is adapted from Riley et al. [12] and Vais et al. [19] with permission. These experiments were performed on HEK293 cells. We refer the interested reader to these two papers for details about experimental methods.

\subsection{Kinetic Model for MCU Function}

Our kinetic model for MCU implements the scheme proposed in Payne et al. [12] and Vais et al. [19]. The model takes into account the explicit dependence of the channel's open probability $\left(P_{O}\right)$ on $\left[\mathrm{Ca}^{2+}\right]_{\mathrm{C}}$, $\left[\mathrm{Ca}^{2+}\right]_{\mathrm{M}}$, and $\Delta \psi$, combining a wide range of observations from patch clamp electrophysiology of individual mitoplasts and fluorescence microscopy of mitochondrial networks in cell cultures. The model assumes $\mathrm{Ca}^{2+}$ sensors on both sides of the IMM. On the cytosolic side, both MICU1 and MICU2 can bind up to two $\mathrm{Ca}^{2+}$ (both MICU1 and MICU2 have two EF hands each and each EF hand can bind one $\mathrm{Ca}^{2+}$ ) (Figure 1A). MICU1 suppresses the activity of MCU in the low $\left[\mathrm{Ca}^{2+}\right]_{C}$ regime $(0-1.3 \mu \mathrm{M})$, whereas MICU2 interacts with MICU1 to increase the $\left[\mathrm{Ca}^{2+}\right]_{C}$ threshold for MCU activation and reduces the gain of cooperative activation of MCU activity. Thus, the channel is open when $\mathrm{Ca}^{2+}$ is bound to both EF hands of MICU1 and MICU2. On the matrix side, MCU activity is regulated by 
coupled inhibitory and activating $\mathrm{Ca}^{2+}$ sensors. At intermediate $\left[\mathrm{Ca}^{2+}\right]_{\mathrm{M}}(50-800 \mathrm{nM}), \mathrm{Ca}^{2+}$ binds to the inhibitory sensor that closes the channel (states $C_{31}$ and $C_{41}$ in the model shown in Figure 1A). At low $\left[\mathrm{Ca}^{2+}\right]_{\mathrm{M}}$, the matrix $\mathrm{Ca}^{2+}$-mediated gatekeeping is released (state $\mathrm{O}_{40}$ ). At high $\left[\mathrm{Ca}^{2+}\right]_{\mathrm{M}}, \mathrm{Ca}^{2+}$ binds to the activating senor, relieving the gatekeeping on the matrix side of the IMM. Our best fit criterion (BIC score) warrants the binding of three $\mathrm{Ca}^{2+}$ to the activating sensor in addition to the one $\mathrm{Ca}^{2+}$ that is bound in state $C_{41}$ to open the channel again (state $O_{44}$ ). More recently, it was shown that the affinities of activating and inhibitory sensors on the matrix side are regulated by another $\mathrm{Ca}^{2+}$ sensor termed "flux sensor" [18]. The flux sensor is believed to represent a site on the matrix side of IMM that binds the $\mathrm{Ca}^{2+}$ as it enters through the channel. This sensor is sensitive to the $\mathrm{Ca}^{2+}$ buffering capacity of mitochondria, especially fast buffers that uptake $\mathrm{Ca}^{2+}$ immediately after entering the matrix. Although our study does not concern the role of mitochondrial $\mathrm{Ca}^{2+}$ buffers, our model can reproduce the observations about the role of "flux sensor" in mitochondrial $\mathrm{Ca}^{2+}$ uptake without changing the topology of the model (results not shown). We also remark that EMRE plays a key role in the matrix $\mathrm{Ca}^{2+}$-mediated regulation of MCU activity, and expressing mutant EMRE abolished this regulation. EMRE is also key to the strong coupling between the mechanisms regulating the channel activity on the matrix and the opposite side of IMM.

Note that, in our model, there are transitions that involve binding of more than one $\mathrm{Ca}^{2+}$. For example, the MCU has 0 and $2 \mathrm{Ca}^{2+}$ bound to the sensors on the cytosolic side of IMM in states $\mathrm{C}_{00}$ and $C_{20}^{M 1}$, respectively. However, the direct link between $C_{00}$ and $C_{20}^{M 1}$ does not necessarily mean that the channel binds $2 \mathrm{Ca}^{2+}$ simultaneously. It rather means that the state with $1 \mathrm{Ca}^{2+}$ bound have very low occupancy and is not required in the model. However, these transition states act as speed-bumps for the probability flux, and their effect can be incorporated in the mean transition times or transition rates. Similarly, for the connectivity of the model, we apply Occam's razor and include the transitions that are warranted by Bayesian Information Criterion [33]. These issues have been discussed in detail elsewhere [34].

The above considerations lead to the kinetic scheme with six close $\left(C_{X Y}\right)$ and two open $\left(O_{X Y}\right)$ states (Figure 1A), where subscripts $X$ and $Y$ represent the number of $\mathrm{Ca}^{2+}$ bound to the domains on the cytosolic and matrix sides of the IMM, respectively. Relative to the reference unliganded close state $C_{00}$, the occupancies (unnormalized probabilities) of the close $C_{X Y}$ and open $O_{X Y}$ states are proportional to $\left(\left[\mathrm{Ca}^{2+}\right]_{C}\right)^{X}\left(\left[\mathrm{Ca}^{2+}\right]_{M}\right)^{Y}$ with occupancy parameters $K_{C_{X Y}}$ and $K_{O_{X Y}}$, respectively. The occupancy parameter of a state is the product of equilibrium association constants along any path connecting $C_{00}$ to that state $\left(K_{C_{00}}=1\right)[34,35]$. In other words, the product of all forward rates starting from $C_{00}$ to a given state $X$ divided by the product of the rates from state $X$ back to $C_{00}$ gives the occupancy of state $X$. This applies to all states and is independent of the path taken from $C_{00}$ to $X$. For example, the ratio of the transition rate from $C_{00}$ to $C_{20}^{M 1}$ to the rate from $C_{20}^{M 1}$ to $C_{00}$ gives the occupancy of $C_{20}^{M 1}$. This will become clear further when we derive the transition rates for the single MCU channel in the Discussion section. We refer the interested reader to [34,35] for a more detailed discussion. Thus, the normalized occupancy of $C_{X Y}$ and $O_{X Y}$ are $\mathrm{K}_{\mathrm{C}_{X Y}}\left(\left[\mathrm{Ca}^{2+}\right]_{\mathrm{C}}\right)^{\mathrm{X}}\left(\left[\mathrm{Ca}^{2+}\right]_{\mathrm{M}}\right)^{\mathrm{Y}} / \mathrm{Z}$ and $\mathrm{K}_{\mathrm{O}_{X Y}}\left(\left[\mathrm{Ca}^{2+}\right]_{\mathrm{C}}\right)^{\mathrm{X}}\left(\left[\mathrm{Ca}^{2+}\right]_{\mathrm{M}}\right)^{\mathrm{Y}} / \mathrm{Z}$, respectively, where $\mathrm{Z}$ is the total occupancy of all states and is given as

$$
\begin{aligned}
& \mathrm{Z}=\mathrm{Z}_{\mathrm{C}}+\mathrm{Z}_{\mathrm{O}}=\left[\begin{array}{c}
1+\mathrm{K}_{\mathrm{C}_{20}^{\mathrm{M} 1}}\left(\left[\mathrm{Ca}^{2+}\right]_{\mathrm{C}}\right)^{2}+\mathrm{K}_{\mathrm{C}_{20}^{\mathrm{M} 2}}\left(\left[\mathrm{Ca}^{2+}\right]_{\mathrm{C}}\right)^{2}+\mathrm{K}_{\mathrm{C}_{30}}\left(\left[\mathrm{Ca}^{2+}\right]_{\mathrm{C}}\right)^{3} \\
+\mathrm{K}_{\mathrm{C}_{31}}\left(\left[\mathrm{Ca}^{2+}\right]_{\mathrm{C}}\right)^{3}\left[\mathrm{Ca}^{2+}\right]_{\mathrm{M}}+\mathrm{K}_{\mathrm{C}_{41}}\left(\left[\mathrm{Ca}^{2+}\right]_{\mathrm{C}}\right)^{4}\left[\mathrm{Ca}^{2+}\right]_{\mathrm{M}}
\end{array}\right] \\
& +\left[\mathrm{K}_{\mathrm{O}_{40}}\left(\left[\mathrm{Ca}^{2+}\right]_{\mathrm{C}}\right)^{4}+\mathrm{K}_{\mathrm{O}_{44}}\left(\left[\mathrm{Ca}^{2+}\right]_{\mathrm{C}}\right)^{4}\left(\left[\mathrm{Ca}^{2+}\right]_{\mathrm{M}}\right)^{4}\right]
\end{aligned}
$$

where $Z_{C}$ and $Z_{O}$ are the unnormalized occupancies of all close and all open states, respectively. The $P_{O}$ of the channel can be written as

$$
P_{O}\left(\left[C a^{2+}\right]_{C^{\prime}}\left[C a^{2+}\right]_{M}\right)=\frac{Z_{O}}{Z_{C}}
$$


The $\mathrm{Ca}^{2+}$ uptake rate of MCU $\left(V_{M C U}\right)$ as a function of $\left[\mathrm{Ca}^{2+}\right]_{\mathrm{C}}$ and $\left[\mathrm{Ca}^{2+}\right]_{\mathrm{M}}$ is given by

$$
\mathrm{V}_{\mathrm{MCU}}=\mathrm{V}_{\mathrm{MCU}, \max } \times \mathrm{P}_{\mathrm{O}}\left(\left[\mathrm{Ca}^{2+}\right]_{\mathrm{C}^{\prime}}\left[\mathrm{Ca}^{2+}\right]_{\mathrm{M}}\right)
$$

where $\mathrm{V}_{\mathrm{MCU}, \max }=600 \mathrm{nM} / \mathrm{s}$ is the maximum uptake rate observed in the cell culture experiments [12]. We remark that the initial $\mathrm{Ca}^{2+}$ uptake rate for each experiment was determined by fitting an exponential function to $\left[\mathrm{Ca}^{2+}\right]_{\mathrm{C}}$ beginning from $\mathrm{Ca}^{2+}$ addition until a new steady-state is reached $300 \mathrm{~s}$ later to obtain parameters A (extent of uptake) and $\tau$ (time constant). The instantaneous rate of uptake at $t=0$ was taken as equal to $\mathrm{A} / \tau$. In these experiments, only mitochondrial $\mathrm{Ca}^{2+}$ uptake through $\mathrm{MCU}$ was active, whereas all other $\mathrm{Ca}^{2+}$ pathways were either pharmacologically blocked or were inactive (see Ref. [12] for details).

\subsection{Whole-Cell $\mathrm{Ca}^{2+}$ Model}

In the cell culture experiments, HEK293 cells were treated with $0.004 \%$ digitonin at $50 \mathrm{~s}$ after the beginning of the experiment to permeabilize plasma membrane in intracellular-like medium lacking free $\mathrm{Ca}^{2+}$ buffers, equilibrating $\mathrm{Ca}^{2+}$ concentration in bath solution and cytoplasm. $\mathrm{Ca}^{2+}$ uptake into the ER and mitochondrial efflux were inhibited by applying $2 \mu \mathrm{M}$ thapsigargin (Sarco/ER Ca ${ }^{2+}$ ATPase (SERCA) blocker) and $20 \mu \mathrm{M}$ CGP37157 $\left(\mathrm{Na}^{+} / \mathrm{Ca}^{2+}\right.$ exchange blocker) at 100 and $400 \mathrm{~s}$, respectively. Similarly, no inositol 1,4,5-trisphosphate $\left(\mathrm{IP}_{3}\right)$ was used in these experiments, implying no $\mathrm{Ca}^{2+}$ efflux from the ER through $\mathrm{IP}_{3}$ receptor $\left(\mathrm{IP}_{3} \mathrm{R}\right)$ channels. After $\left[\mathrm{Ca}^{2+}\right]_{\mathrm{C}}$ reached a steady-state at $700 \mathrm{~s}$, MCU-mediated $\mathrm{Ca}^{2+}$ uptake was initiated by adding boluses of $\mathrm{CaCl}_{2}$ to achieve increases in $\left[\mathrm{Ca}^{2+}\right]_{\mathrm{C}}$ between $100 \mathrm{nM}$ and $10 \mu \mathrm{M}$. All these considerations lead to the following rate equations for $\left[\mathrm{Ca}^{2+}\right]_{\mathrm{C}}$ and $\left[\mathrm{Ca}^{2+}\right]_{\mathrm{M}}$, respectively.

$$
\begin{gathered}
\frac{\mathrm{d}\left[\mathrm{Ca}^{2+}\right]_{\mathrm{C}}}{\mathrm{dt}}=\left(\mathrm{V}_{\mathrm{Stim}}-\mathrm{V}_{\mathrm{MCU}}+\mathrm{V}_{\text {Leak }}\right), \\
\frac{\mathrm{d}\left[\mathrm{Ca}^{2+}\right]_{\mathrm{M}}}{\mathrm{dt}}=\mathrm{f}_{\mathrm{m}} \times \mathrm{V}_{\mathrm{MCU}} / \delta
\end{gathered}
$$

where $V_{\text {Stim }}$ represents $\mathrm{Ca}^{2+}$ stimulus (bolus of $\mathrm{CaCl}_{2}$ ). The value of $V_{\text {Stim }}$ is set so that the peak $\left[\mathrm{Ca}^{2+}\right]_{\mathrm{C}}$ given by the model matches the observed value. Parameters $f_{m}=3 \times 10^{-4}$ and $\delta=0.067$ are the $\mathrm{Ca}^{2+}$ buffering of mitochondria and the ratio of mitochondrial to cytosolic volume [36,37]. As we will see later, both of these parameters significantly affect free $\left[\mathrm{Ca}^{2+}\right]_{\mathrm{M}}$. We add $V_{\text {Leak }}$ to the rate equation for $\left[\mathrm{Ca}^{2+}\right]_{C}$ to incorporate the effect of potential $\mathrm{Ca}^{2+}$ leak from the ER to the cytoplasm:

$$
\mathrm{V}_{\text {Leak }}=\mathrm{V}_{\text {leak,max }}\left(\left[\mathrm{Ca}^{2+}\right]_{\mathrm{ER}}-\left[\mathrm{Ca}^{2+}\right]_{\mathrm{C}}\right),
$$

where $\left[\mathrm{Ca}^{2+}\right]_{\mathrm{ER}}=200 \mu \mathrm{M}$ is $\mathrm{Ca}^{2+}$ concentration in the ER.

\subsection{The Effect of MICU1 or MICU2 KO on Mitochondrial Function at the Whole-Cell Level}

To assess how MICU1 or MICU2 KO affect mitochondrial function, we extend the model to incorporate the dynamics of mitochondrial $\mathrm{NADH}$ concentration $\left([\mathrm{NADH}]_{\mathrm{M}}\right)$, mitochondrial ADP concentration $\left([\mathrm{ADP}]_{\mathrm{M}}\right), \Delta \psi$, and cytosolic ADP concentration $\left([\mathrm{ADP}]_{\mathrm{C}}\right)$. The rate equations, relevant fluxes (with the exception of $V_{\mathrm{MCU}}$ and $V_{\mathrm{NaCa}}$ ), and parameters are adopted from Ref. [36] and are given in the Supplementary Information Text. Furthermore, Equation (5) is modified slightly to include $\mathrm{Ca}^{2+}$ efflux from the mitochondria through $\mathrm{Na}^{+} / \mathrm{Ca}^{2+}$ exchanger $\left(V_{\mathrm{NaCa}}\right)$ [38].

$$
\frac{\mathrm{d}\left[\mathrm{Ca}^{2+}\right]_{\mathrm{M}}}{\mathrm{dt}}=\mathrm{f}_{\mathrm{m}} \times\left(\mathrm{V}_{\mathrm{MCU}}-\mathrm{V}_{\mathrm{NaCa}}\right) / \delta
$$


where

$$
\mathrm{V}_{\mathrm{NaCa}}=\mathrm{V}_{\mathrm{NaCa}, \max } \frac{\left(\frac{\left[\mathrm{Ca}^{2+}\right]_{\mathrm{M}}}{\left[\mathrm{Ca}^{2+}\right]_{\mathrm{C}}}\right) \exp \left(\frac{\mathrm{bF}\left(\Delta \psi-\Delta \psi_{0}\right)}{\mathrm{RT}}\right)}{\left(1+\frac{\mathrm{K}_{\mathrm{Na}}}{[\mathrm{Na}]_{\mathrm{i}}}\right)^{3}\left(1+\frac{\mathrm{K}_{\mathrm{Ca}}}{\left[\mathrm{Ca}^{2+}\right]_{\mathrm{M}}}\right)},
$$

where $b=0.5, \Delta \psi_{0}=91 \mathrm{mV}, K_{N a}=9.4 \times 10^{3} \mu \mathrm{M}$, and $K_{C a}=0.375 \mu \mathrm{M} .[\mathrm{Na}]_{\mathrm{i}}=11 \times 10^{3} \mu \mathrm{M}, F, R$, and $\mathrm{T}=310.16^{\circ} \mathrm{K}$ is the cytosolic $\mathrm{Na}^{+}$concentration, Faraday's constant, gas constant, and temperature, respectively. Note that $\Delta \psi_{0}=91 \mathrm{mV}$ does not represent the resting MMP. It was originally selected so that $V_{\mathrm{NaCa}}$ is maximum when $\Delta \psi=\Delta \psi_{0}$, i.e., under uncoupled conditions [38]. As we discuss later, $V_{\mathrm{NaCa} \text {,max }}$ is estimated from the observed values of resting $\left[\mathrm{Ca}^{2+}\right]_{\mathrm{M}}$ in WT, MICU1, and MICU2 $\mathrm{KO}$ conditions. The full model used for mitochondrial function at the whole-cell level consists of Equations (7) (with Equations (3) and (8)) and Equations (S1)-(S4) (Section "Bioenergetics model" in the Supplementary Information Text). Equation (3) is multiplied by Equation (9) given below to incorporate the voltage dependence of $V_{M C U}$.

\section{Results}

\subsection{The Model Reproduces the Function of MCU both at Cell Culture and Single Mitoplast Levels}

Model fits to the mitochondrial $\mathrm{Ca}^{2+}$ uptake rate as a function of $\left[\mathrm{Ca}^{2+}\right]_{\mathrm{C}}$ observed in cell cultures using fluorescence microscopy on WT (spheres, solid line), MICU1 KO (squares, dashed line), and MICU2 KO (diamonds, dashed-dotted line) cells are shown in Figure 1B. The values of occupancy parameters for the three conditions are given in Table S2. The model closely reproduces the general features of the MCU activity including the suppressed activity in the low $\left[\mathrm{Ca}^{2+}\right]_{\mathrm{C}}$ regime $(0-1.3 \mu \mathrm{M})$, the cooperative opening once the gatekeeping is relieved, relief of gatekeeping and reduced cooperative activation in MICU1 KO cells, and reduced threshold for gatekeeping and increased gain of cooperative activation in MICU2 KO cells. We remark that our fitting criterion searches for the parameters that result in the best fit to all observations simultaneously. For example, in case of MICU1 KO experiments, we do not restrict our search to states that are associated with MICU1 only. In other words, we make no a priori assumption about the independent binding of $\mathrm{Ca}^{2+}$ to the MICU1 EF hands. This is motivated by the complex structure of MCU $[5,8,9,39]$ and the understanding that "the protein is not a rigid system in which a ligand moves in a fixed potential. Instead, there is a strong mutual interaction between ligand and protein" [40] that affects several aspects of the channel gating. This approach leads to an interesting observation in our model: MICU1 (or MICU2) KO not only affects the probability of states associated with MICU1 but also change the occupancy of other binding sites (Table S2).

Notice that the model uses the values of both $\left[\mathrm{Ca}^{2+}\right]_{\mathrm{C}}$ and $\left[\mathrm{Ca}^{2+}\right]_{\mathrm{M}}$ for the fit. However, the experiments on cell cultures report the uptake rate as a function of $\left[\mathrm{Ca}^{2+}\right]_{C}$, whereas the values of $\left[\mathrm{Ca}^{2+}\right]_{\mathrm{M}}$ at the $\left[\mathrm{Ca}^{2+}\right]_{\mathrm{C}}$ used are not known. In one set of experiments, Vias et al. [19] measured $\left[\mathrm{Ca}^{2+}\right]_{\mathrm{C}}$ and $\left[\mathrm{Ca}^{2+}\right]_{\mathrm{M}}$ simultaneously (without measuring MCU activity) (see Figure 3J,K in Ref. [19]). We use the values from those experiments to derive a rough estimate of $\left[\mathrm{Ca}^{2+}\right]_{\mathrm{M}}$ as a function of $\left[\mathrm{Ca}^{2+}\right]_{\mathrm{C}}$ in MICU2 $\mathrm{KO}$ cells. That is, we plot $\left[\mathrm{Ca}^{2+}\right]_{\mathrm{M}}$ versus $\left[\mathrm{Ca}^{2+}\right]_{C}$ from these experiments and interpolate this relationship to other $\left[\mathrm{Ca}^{2+}\right]_{C}$ values. These estimates are crude because the peak $\left[\mathrm{Ca}^{2+}\right]_{\mathrm{C}}$ value used in those experiments was less than $1 \mu \mathrm{M}$, whereas the values used in Figure $1 \mathrm{~B}$ go beyond $8 \mu \mathrm{M}$. We believe that this information gap could be causing the discrepancy between the model and observations in the MICU2 KO cells (Figure 1B). We noticed that another set of parameters give a closer fit to the uptake rate observed in the MICU2 KO cell culture, but it deteriorates the fit to the MCU current ( $\mathrm{I}_{\mathrm{MCU}}$ ) observed at the single mitoplast level [19] (Figure S1). Since both $\left[\mathrm{Ca}^{2+}\right]_{\mathrm{C}}$ and $\left[\mathrm{Ca}^{2+}\right]_{\mathrm{M}}$ are known in the patch clamp experiments, we choose the first set of parameters (Table S2) over the second for the rest of this paper. 
Payne et al. [12] suggested that the state with $\mathrm{Ca}^{2+}$ bound to both EF hands of MICU1 and one EF hand of MICU2 is an open state. To test this hypothesis, we change the state $C_{30}$ in the model to an open state $\left(\mathrm{O}_{30}\right)$. However, we found that such change is not supported as the model predicts higher $\mathrm{Ca}^{2+}$ uptake rate in WT cells (Figure S2A). Furthermore, the overall fit to the observed uptake rate in MICU1 KO cells significantly deteriorates (Figure S2B). We therefore leave this state as a close state from now on.

In our formalism, the transition from whole-cell model (based on cell culture experiments) to the single mitoplast model is straightforward. The only parameter that changes while fitting to the single mitoplast data is that $V_{M C U, \max }$ in Equation (3) is replaced by the maximum value of MCU current density $\left(\mathrm{I}_{\mathrm{MCU}} / \mathrm{C}_{\mathrm{m}}\right)$ observed in patch clamp experiments, which is equal to 206, 237, and 217 $\mathrm{pA} / \mathrm{pF}$ in case of WT, MICU1 KO, and MICU2 KO mitoplasts, respectively. The model fits a range of observations about individual mitoplasts. The theoretical curves mirror the inverted bell-shaped behavior of $\mathrm{I}_{\mathrm{MCU}} / \mathrm{C}_{\mathrm{m}}$ as a function of $\left[\mathrm{Ca}^{2+}\right]_{\mathrm{M}}$ and the lack of inhibition in the MICU1 KO and MICU2 $\mathrm{KO}$ mitoplasts (Figure 1C). We also look at the maximum value of $\mathrm{I}_{\mathrm{MCU}} / \mathrm{C}_{\mathrm{m}}$ at different $\left[\mathrm{Ca}^{2+}\right]_{\mathrm{C}}$ and fixed $\left[\mathrm{Ca}^{2+}\right]_{\mathrm{M}}=0.4 \mu \mathrm{M}$. Apart from the apparent mismatch between theory and experiment in case of MICU1 KO mitoplasts (Figure 1D, triangles and dashed line), the model exhibits the same general trend in WT and MICU2 KO mitoplasts (Figure 1D). The discrepancy in case of MICU1 KO could be due to the fact that the model represents MICU1 KO mitoplasts, whereas the experimental data are from MICU1 knockdown mitoplasts and is shown only for a crude comparison due to the lack of such data on MICU1 KO mitoplasts. Indeed, the overall theoretical trend is consistent with the observations in Figure 1C (squares and dashed line) where the current through MCU in MICU1 KO mitoplasts is larger than both the WT and MICU2 KO mitoplasts. The model reproduces MCU current density at different $\left[\mathrm{Ca}^{2+}\right]_{\mathrm{C}}$ and fixed $\left[\mathrm{Ca}^{2+}\right]_{\mathrm{M}} \sim 0 \mu \mathrm{M}$ (Figure 1E, spheres and solid line). While we do not have experimental data on MICU1 KO and MICU2 KO mitoplasts, model predictions for these two cases are shown in Figure $1 \mathrm{E}$ by the dashed and dashed-dotted lines, respectively.

\subsection{The Relief from Mitochondrial $\mathrm{Ca}^{2+}$-Mediated Gatekeeping at Low $\left[\mathrm{Ca}^{2+}\right]_{M}$ Decreases as We Decrease $\left[\mathrm{Ca}^{2+}\right]_{C}$}

We saw in the previous section that the MCU current density exhibits an inverted bell-shaped behavior as we change $\left[\mathrm{Ca}^{2+}\right]_{\mathrm{M}}$ with a minimum (a maximum suppression of $75 \%$ ) at $0.4 \mu \mathrm{M}$ at $\left[\mathrm{Ca}^{2+}\right]_{\mathrm{C}}=1 \mathrm{mM}$ in WT mitoplasts (Figure $1 \mathrm{C}$, spheres and solid line). This matrix $\mathrm{Ca}^{2+}$-mediated gatekeeping is relieved when $\left[\mathrm{Ca}^{2+}\right]_{\mathrm{M}}$ decreases or increases from $0.4 \mu \mathrm{M}$. As the model enables us to estimate the current density as we vary $\left[\mathrm{Ca}^{2+}\right]_{\mathrm{C}}$ and $\left[\mathrm{Ca}^{2+}\right]_{\mathrm{M}}$ simultaneously in a continuous manner, we next tested this inverted bell-shaped behavior at varying $\left[\mathrm{Ca}^{2+}\right]_{\mathrm{C}}$. We found that, while the gatekeeping remains intact, the recovery from it (on the low $\left[\mathrm{Ca}^{2+}\right]_{\mathrm{M}}$ side) shifts to even lower $\left[\mathrm{Ca}^{2+}\right]_{\mathrm{M}}$ values and eventually disappears as we decrease $\left[\mathrm{Ca}^{2+}\right]_{C}$ (Figure $2 \mathrm{~A}$ ). As is clear from Figure $2 \mathrm{~B}$, this behavior is also supported by observations where we show the ratio of MCU current density observed in WT mitoplasts at $\left[\mathrm{Ca}^{2+}\right]_{\mathrm{M}}=0 \mu \mathrm{M}$ to that observed at $\left[\mathrm{Ca}^{2+}\right]_{\mathrm{M}}=0.4 \mu \mathrm{M}$ at different $\left[\mathrm{Ca}^{2+}\right]_{\mathrm{C}}$ values. The ratio decreases significantly as we decrease $\left[\mathrm{Ca}^{2+}\right]_{\mathrm{C}}$, eventually reaching 1 at $\left[\mathrm{Ca}^{2+}\right]_{\mathrm{C}}=0 \mu \mathrm{M}$. On the high $\left[\mathrm{Ca}^{2+}\right]_{M}$ side, the recovery from gatekeeping shifts to even higher $\left[\mathrm{Ca}^{2+}\right]_{M}$ values as we decrease $\left[\mathrm{Ca}^{2+}\right]_{\mathrm{C}}$ (Figure $2 \mathrm{~A}$ ). In other words, the range of $\left[\mathrm{Ca}^{2+}\right]_{\mathrm{M}}$ values where gatekeeping is effective gets narrower as $\left[\mathrm{Ca}^{2+}\right]_{C}$ increases. This, together with the cooperative opening of MCU once the gatekeeping on the cytosolic side is relieved, could potentially lead to a vicious cycle, leaving mitochondria increasingly vulnerable to $\mathrm{Ca}^{2+}$ overload and the opening of mitochondrial permeability transition pore $[41]$ as $\left[\mathrm{Ca}^{2+}\right]_{\mathrm{C}}$ increases beyond a certain limit. 


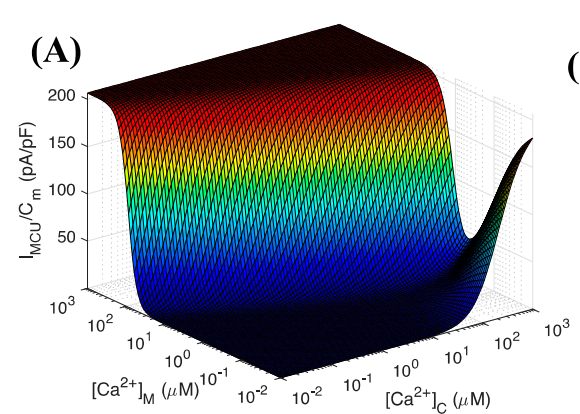

(C)

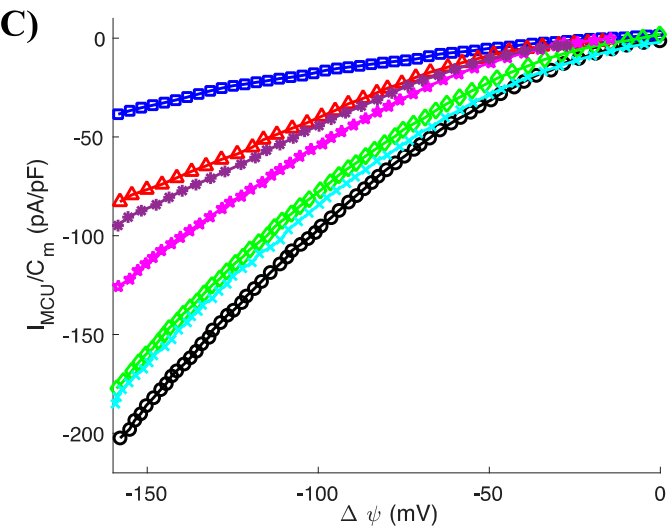

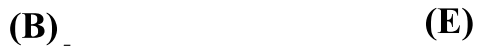

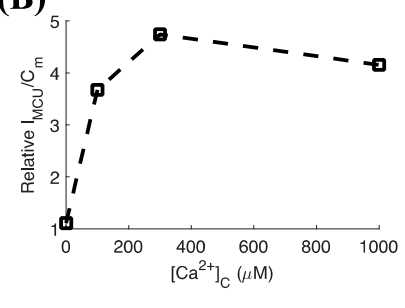

(E)

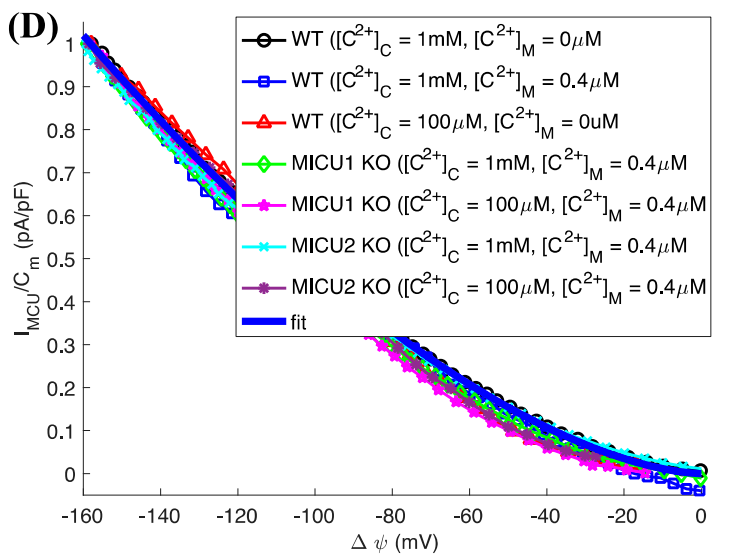

Figure 2. MCU current density as a function of $\left[\mathrm{Ca}^{2+}\right]_{C},\left[\mathrm{Ca}^{2+}\right]_{\mathrm{M}}$, and $\Delta \psi$. (A) The inverted bell-shaped behavior of the $\mathrm{MCU} \mathrm{Ca}{ }^{2+}$ flux changes into a biphasic behavior with almost zero and optimal current density at low and high $\left[\mathrm{Ca}^{2+}\right]_{\mathrm{M}}$ respectively as we decrease $\left[\mathrm{Ca}^{2+}\right]_{C} ;(\mathbf{B})$ the ratio of $\mathrm{I}_{\mathrm{MCU}} / \mathrm{C}_{\mathrm{m}}$ observed at $\left[\mathrm{Ca}^{2+}\right]_{\mathrm{M}}=0 \mu \mathrm{M}$ to that observed at $\left[\mathrm{Ca}^{2+}\right]_{\mathrm{M}}=0.4 \mu \mathrm{M}$ in WT mitoplasts at different $\left[\mathrm{Ca}^{2+}\right]_{\mathrm{C}}$ values. (C) raw and (D) normalized $\mathrm{I}_{\mathrm{MCU}} / \mathrm{C}_{\mathrm{m}}$ (normalized with respect to the minima (maximum $\mathrm{Ca}^{2+}$ influx) of the trace) at different $\left[\mathrm{Ca}^{2+}\right]_{\mathrm{C}}$ and $\left[\mathrm{Ca}^{2+}\right]_{\mathrm{M}}$ values as we vary $\Delta \psi$ in WT, MICU1 KO, and MICU2 KO mitoplasts. Thick solid line in (D) represents model fit; $(\mathrm{E}) \mathrm{I}_{\mathrm{MCU}} / \mathrm{C}_{\mathrm{m}}$ given by the model as a function of $\left[\mathrm{Ca}^{2+}\right]_{\mathrm{M}}$ and $\Delta \psi$ at $\left[\mathrm{Ca}^{2+}\right]_{\mathrm{C}}=100 \mu \mathrm{M}$. Experimental data shown for comparison is from [19] (B-D).

\subsection{Membrane Potential Dependence of MCU Current Density}

Membrane potential $(\Delta \psi)$ is another key variable influencing current through MCU by providing a driving force for $\mathrm{Ca}^{2+}$ influx. Figure $2 \mathrm{C}$ shows that the inward current density through MCU decreases as we make mitochondrial membrane more depolarized. While the amplitude of $\mathrm{I}_{\mathrm{MCU}} / \mathrm{C}_{\mathrm{m}}$ changes as we change $\left[\mathrm{Ca}^{2+}\right]_{\mathrm{C}},\left[\mathrm{Ca}^{2+}\right]_{\mathrm{M}}$, and knockout MICU1 or MICU2, normalizing all traces with respect to their respective peak values shows that they follow the same functional form with respect to $\Delta \psi$. Thus, we use the following function to represent the $\Delta \psi$ dependence of $\mathrm{Ca}^{2+}$ flux through MCU:

$$
\mathrm{f}(\Delta \psi)=\mathrm{A}(-\Delta \psi)^{\mathrm{b}}
$$

where $\mathrm{A}=1.62349$ and $\mathrm{b}=2.69 \times 10^{-4}$. Fit to $\mathrm{I}_{\mathrm{MCU}} / \mathrm{C}_{\mathrm{m}}$ given by the model is shown by the thick solid line in Figure 2D. Multiplying Equations (3) and (9) leads to a complete model for MCU Ca ${ }^{2+}$ uptake rate as a function of $\left[\mathrm{Ca}^{2+}\right]_{\mathrm{C}},\left[\mathrm{Ca}^{2+}\right]_{\mathrm{M}}$, and $\Delta \psi$. In Figure $2 \mathrm{E}$, we show $\mathrm{I}_{\mathrm{MCU}} / \mathrm{C}_{\mathrm{m}}$ predicted by the model as a function of $\left[\mathrm{Ca}^{2+}\right]_{\mathrm{M}}$ and $\Delta \psi$ at $\left[\mathrm{Ca}^{2+}\right]_{\mathrm{C}}=100 \mu \mathrm{M}$. We choose this value for $\left[\mathrm{Ca}^{2+}\right]_{\mathrm{C}}$ because of its physiological relevance, as $\mathrm{Ca}^{2+}$ concentration in the microdomain formed by the close apposition of mitochondrion with the ER or plasma membrane reaches similar values when the $\mathrm{Ca}^{2+}$ channels on these membranes are open $[23,42,43]$.

The interplay between $\left[\mathrm{Ca}^{2+}\right]_{\mathrm{C}},\left[\mathrm{Ca}^{2+}\right]_{\mathrm{M}}$, and $\Delta \psi$ constitutes a robust signaling mechanism, controlling mitochondrial function. For example, raising $\left[\mathrm{Ca}^{2+}\right]_{C}$ by a few $\mu \mathrm{M}$ increases $\left[\mathrm{Ca}^{2+}\right]_{\mathrm{M}}$ by a few tens of $\mu \mathrm{M}[44,45]$. Such concentrations would cause the gatekeeping on both sides of the IMM to relieve, resulting in a maximum flux through MCU $[12,19]$. Furthermore, normalized TMRE 
fluorescence representing membrane potential $(\Delta \psi)$ increases by more than 0.1 on a 0.5 to 1 scale (where 1 represents the complete dissipation of the potential difference across IMM) when $\left[\mathrm{Ca}^{2+}\right]_{\mathrm{C}}$ is raised by $5 \mu \mathrm{M}$ in patch clamp experiments on WT mitoplasts (see Figure S3 in Ref. [12]). The drop in $\Delta \psi$ would cause a decrease in $\mathrm{Ca}^{2+}$ uptake by mitochondria, giving another crucial control to these key variables to regulate mitochondrial function. We remark that all analysis in Figure 2 is applicable to MCU function at the cell culture level except that the peak $\mathrm{I}_{\mathrm{MCU}} / \mathrm{C}_{\mathrm{m}}(206 \mathrm{pA} / \mathrm{pF})$ gets replaced by the maximum uptake rate observed at the whole-cell level $(600 \mathrm{nM} / \mathrm{s})$.

\subsection{Model Fits to the Whole-Cell $\mathrm{Ca}^{2+}$ Signals}

Before making predictions, we show that the model closely fits the observed whole-cell cytosolic $\mathrm{Ca}^{2+}$ dynamics when WT, MICU1 KO, and MICU2 KO cells are challenged with an acute increase of different amounts of $\left[\mathrm{Ca}^{2+}\right]_{C}$ in the cell culture experiments (Figure 3). At very high $\left[\mathrm{Ca}^{2+}\right]_{C}(>7 \mu \mathrm{M})$, the higher $V_{M C U}$ causes [ $\left.\mathrm{Ca}^{2+}\right]_{C}$ in MICU2 KO to drop significantly faster than both WT and MICU1 $\mathrm{KO}$ cells (Figure $3 \mathrm{~A})$. As $\left[\mathrm{Ca}^{2+}\right]_{C}$ drops to lower values, $V_{M C U}$ in MICU1 KO cells remains elevated longer than that in WT and MICU2 KO cells, bringing $\left[\mathrm{Ca}^{2+}\right]_{\mathrm{C}}$ in MICU1 KO cells below that in WT and MICU2 KO cells. The trajectories at lower $\left[\mathrm{Ca}^{2+}\right]_{\mathrm{C}}$ bolus also follows a similar trend (Figure 3B).

The peak $\left[\mathrm{Ca}^{2+}\right]_{\mathrm{M}}$ (peak free $\mathrm{Ca}^{2+}$ in the mitochondria) given by the model is an order of magnitude lower than that observed experimentally (Figure 3C,D). For example, raising $\left[\mathrm{Ca}^{2+}\right]_{\mathrm{C}}$ close to $800 \mathrm{nM}$ in WT cells increases $\left[\mathrm{Ca}^{2+}\right]_{\mathrm{M}}$ to more than $1 \mu \mathrm{M}$ (Figure 3J,K in Ref. [12]). However, the $\mathrm{Ca}^{2+}$ buffering capacity of mitochondria $\left(f_{m}\right)$ and the relative volume of mitochondria with respect to cytosol $(\delta)$ both play key roles in the free $\left[\mathrm{Ca}^{2+}\right]_{\mathrm{M}}$. We repeat the simulation in Figure $3 \mathrm{~A}$ for WT cells using $\mathrm{Ca}^{2+}$ bolus of different strengths and record the peak $\left[\mathrm{Ca}^{2+}\right]_{\mathrm{C}}$ during the simulation and $\left[\mathrm{Ca}^{2+}\right]_{\mathrm{M}} 300 \mathrm{~s}$ after the $\mathrm{Ca}^{2+}$ bolus is added to the cytoplasm. As shown in Figure 3E,F, the peak free mitochondrial $\mathrm{Ca}^{2+}$ increases dramatically as we increase $f_{m}$ (decreasing mitochondrial $\mathrm{Ca}^{2+}$ buffering capacity) or decrease $\delta$ (decreasing the relative mitochondrial volume). Using the simultaneously measured values of $\left[\mathrm{Ca}^{2+}\right]_{C}$ and $\left[\mathrm{Ca}^{2+}\right]_{M}$ from Ref. [12] as a reference, we found that $f_{m} \sim 0.09$ results in a close correspondence between $\left[\mathrm{Ca}^{2+}\right]_{C}$ and $\left[\mathrm{Ca}^{2+}\right]_{M}$ when $\delta=0.067$ is considered. The $f_{m}$ value giving the correct correspondence between model and observations would decrease (higher mitochondrial $\mathrm{Ca}^{2+}$ buffering capacity) as we decrease $\delta$. 

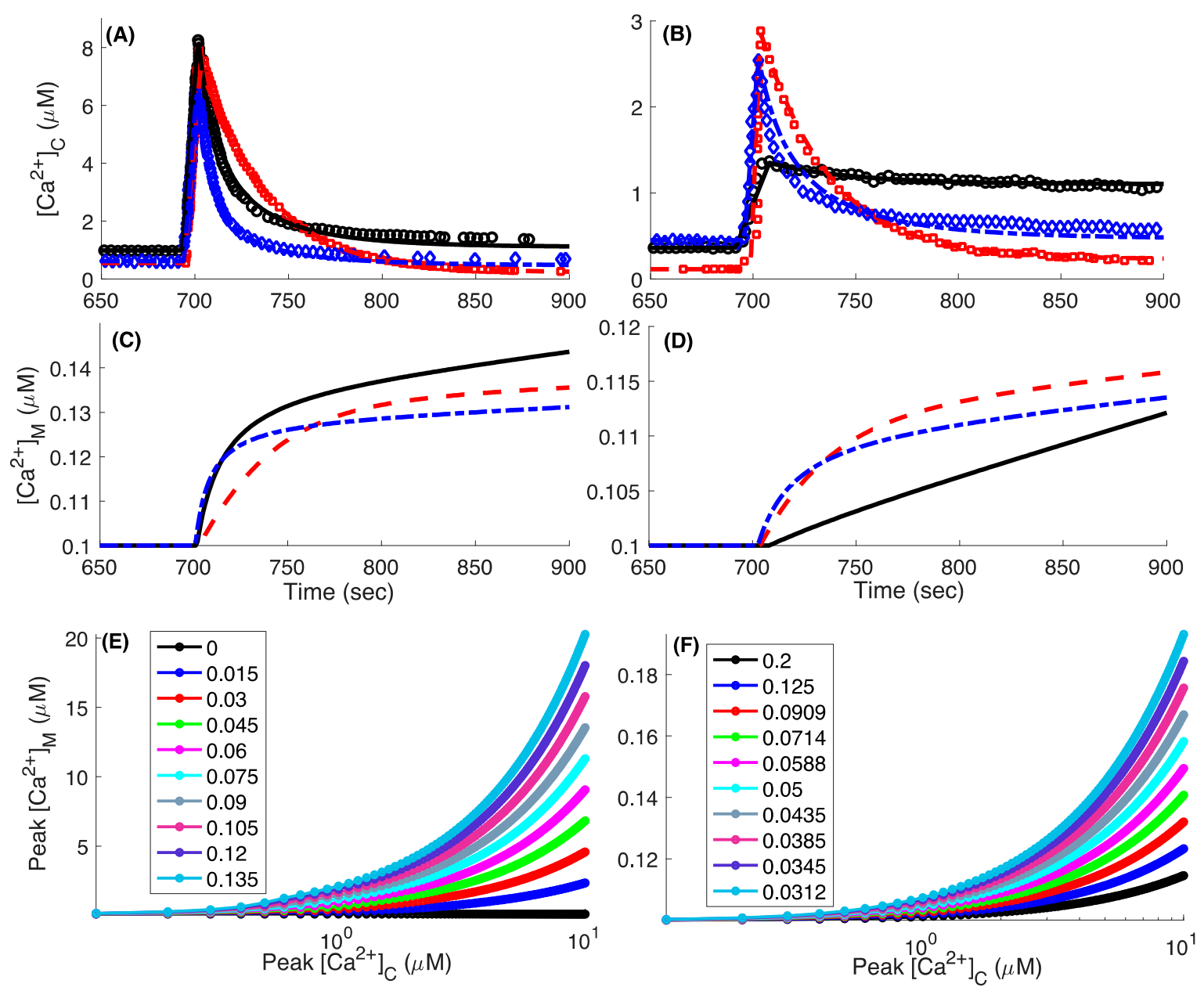

Figure 3. Model fits to the whole-cell cytosolic $\mathrm{Ca}^{2+}$ traces observed in the cell culture experiments and the effect of mitochondrial $\mathrm{Ca}^{2+}$ buffering capacity and relative size with respect to cytoplasm on free mitochondria $\mathrm{Ca}^{2+}$. (A) $\left[\mathrm{Ca}^{2+}\right]_{C}$ in WT (spheres, solid line), MICU1 KO (squares, dashed line), MICU2 $\mathrm{KO}$ (diamonds, dashed-dotted line) cells. Symbols and lines represent experimental observations and model fits respectively. Cells were treated with $0.004 \%$ digitonin to permeabilize plasma membrane, $2 \mu \mathrm{M}$ thapsigargin to block ER Ca ${ }^{2+}$ uptake, and $20 \mu \mathrm{M}$ CGP37157 to inhibit mitochondrial $\mathrm{Ca}^{2+}$ efflux, added at $\mathrm{t}=50,100$, and $400 \mathrm{~s}$, respectively. After reaching steady state, a bolus of $\mathrm{Ca}^{2+}$ was added to the cytoplasm at $\sim 700 \mathrm{~s}$ to raise $\left[\mathrm{Ca}^{2+}\right]_{C}$ to above $7 \mu \mathrm{M}$. (C) $\left[\mathrm{Ca}^{2+}\right]_{\mathrm{M}}$ given by the model. Results in $(\mathbf{B}, \mathbf{D})$ are similar to $(\mathbf{A}, \mathbf{C})$ except that the bolus of $\mathrm{Ca}^{2+}$ added was smaller. Peak $\left[\mathrm{Ca}^{2+}\right]_{\mathrm{M}} 300 \mathrm{~s}$ after the $\mathrm{Ca}^{2+}$ bolus was added as a function of maximum $\left[\mathrm{Ca}^{2+}\right]_{C}$ in WT cells as we change $f_{m}(\mathbf{E})$ and $\delta(\mathbf{F})$. The legends in $(\mathbf{E}, \mathbf{F})$ respectively represent the values of $f_{m}$ and $\delta$ used. In all simulations shown in Figure 3, a fixed mitochondrial membrane potential $\Delta \psi=-160 \mathrm{mV}$ is used. Experimental data shown for comparison are from [12] (A,B).

\subsection{Mitochondrial Bioenergetics in WT, MICU1 KO, and MICU2 KO Cells}

In simulations shown in Figure $3, \Delta \psi$ is kept fixed at $-160 \mathrm{mV}$. However, $\Delta \psi$ changes as mitochondria buffers $\mathrm{Ca}^{2+}$. We therefore extend our model for mitochondrial $\mathrm{Ca}^{2+}$ uptake at the whole-cell level to incorporate the dynamic behavior of $\Delta \psi$ and how mitochondrial NADH $\left([\mathrm{NADH}]_{\mathrm{M}}\right)$ and ATP $\left([\mathrm{ATP}]_{\mathrm{M}}\right)$ change as mitochondria buffer $\mathrm{Ca}^{2+}$ in WT, MICU1 KO, and MICU2 KO cells. A key parameter missing in our whole-cell $\mathrm{Ca}^{2+}$ model is the maximum flux through $\mathrm{Na}^{+} / \mathrm{Ca}^{2+}$ exchanger $\left(V_{\mathrm{NaCa} \text { max }}\right.$ in Equaiton (8)). Although we do not have direct access to this parameter in our experimental results, we use the observed resting value of $\left[\mathrm{Ca}^{2+}\right]_{\mathrm{M}}$ to estimate $V_{\mathrm{NaCa} \text {,max }}$. Knowing that the $\mathrm{Ca}^{2+}$ fluxes through MCU and $\mathrm{Na}^{+} / \mathrm{Ca}^{2+}$ exchanger balance each other out in resting conditions [27], and the MCU flux is constrained by the observations discussed above, we vary $V_{\mathrm{NaCa}, \max }$ until $\left[\mathrm{Ca}^{2+}\right]_{\mathrm{M}}$ given 
by the model in resting state matches the observed value (Figure S3). The values given by the fit in WT, MICU1 KO, and MICU2 KO conditions at the whole-cell level are given in the legends of Figure S3. In line with the observations where the deregulated mitochondrial $\mathrm{Ca}^{2+}$ uptake due to the loss of MICU1 function is shown to initiate a futile cycle whereby continuous $\mathrm{Ca}^{2+}$ influx is balanced by efflux through $\mathrm{Na}^{+} / \mathrm{Ca}^{2+}$ exchange [27], our model predicts higher $V_{\mathrm{NaCa}, \max }$ in MICU1 KO cells $(2.144 \mathrm{nM} / \mathrm{s})$ when compared to WT cells $(0.958 \mathrm{nM} / \mathrm{s})$.

After reaching steady state, we apply a square pulse of $\mathrm{Ca}^{2+}$ to the cytoplasm, raising $\left[\mathrm{Ca}^{2+}\right]_{\mathrm{C}}$ from its resting value of $0.1 \mu \mathrm{M}$ to $1.5 \mu \mathrm{M}$ to see how key mitochondrial variables respond to the $\left[\mathrm{Ca}^{2+}\right]_{\mathrm{C}}$ rise in the three conditions. Typical time traces of $\left[\mathrm{Ca}^{2+}\right]_{\mathrm{M}}, \Delta \psi,[\mathrm{NADH}]_{\mathrm{M}}$, and $[\mathrm{ATP}]_{\mathrm{M}}$ are shown in Figure S3. In resting condition, MICU1 KO cell has higher $\left[\mathrm{Ca}^{2+}\right]_{M}$ (Figure S3A) and slightly hyperpolarized IMM (Figure S3B) when compared with WT and MICU2 KO cells, which mainly results from the higher $[\mathrm{NADH}]_{\mathrm{M}}$ (Figure $\mathrm{S3C}$ ) that also leads to higher $[\mathrm{ATP}]_{\mathrm{M}}$ in resting conditions (Figure S3D). The small depolarization in IMM as soon as $\left[\mathrm{Ca}^{2+}\right]_{C}$ is increased (note the very small increase in $\Delta \psi$ before the relatively large decrease) results from the $\mathrm{Ca}^{2+}$ and $\mathrm{Na}^{+}$influx through $\mathrm{MCU}$ and $\mathrm{Na}^{+} / \mathrm{Ca}^{2+}$ exchanger, respectively. The small depolarization is followed by a relatively large hyperpolarization (although still very small in absolute terms), mainly due to the increase in $[\mathrm{NADH}]_{\mathrm{M}}$ that in turn results from the stimulation of the pyruvate dehydrogenase reaction. While the values of $[\mathrm{NADH}]_{\mathrm{M}}, \Delta \psi$ (more hyperpolarized), and $[\mathrm{ATP}]_{\mathrm{M}}$ in resting conditions are larger, the relative change in all these variables in response to the $\mathrm{Ca}^{2+}$ bolus is smaller in MICU1 KO cells as compared to both WT and MICU2 KO cells. The relative smaller increase in $[\mathrm{ATP}]_{\mathrm{M}}$ in response to $\left[\mathrm{Ca}^{2+}\right]_{\mathrm{C}}$ rise is consistent with the observations by Bhosale et al. [27] showing that the futile $\mathrm{Ca}^{2+}$ cycle due to uninhibited MCU influx balanced by larger efflux through $\mathrm{Na}^{+} / \mathrm{Ca}^{2+}$ exchanger leads to a lower ATP production in cells with MICU1 mutations.

\section{6. $\mathrm{Ca}^{2+}$ Uptake and Bioenergetics at the Single Mitoplast Level}

There are two main discrepancies between $\Delta \psi$ given by the model at the whole-cell level and that observed experimentally in the cell culture experiments (see Figure S3 in Ref. [12]). First, the observed IMM potential in MICU1 KO cells is more depolarized than the WT and MICU2 KO cells. Second, the observed depolarization of IMM after the application of $\mathrm{Ca}^{2+}$ bolus is significantly larger when compared to the model predictions where the depolarization due to $\mathrm{Ca}^{2+}$ influx is almost unnoticeable. This is mainly due to the fact that the estimated maximum flux through MCU at the whole-cell level is small as it represents the average uptake of the entire mitochondrial network in the cell culture. That is, it represents the rate at which the average extra-mitochondrial $\mathrm{Ca}^{2+}$ in the cell culture decreases due to the net uptake by the entire mitochondrial network. Similarly, $\left[\mathrm{Ca}^{2+}\right]_{\mathrm{C}}$ and $\left[\mathrm{Ca}^{2+}\right]_{\mathrm{M}}$ also represent the average concentrations and ignore the large concentration gradients that could occur in the microdomain formed by the close apposition of a mitochondrion and the ER. In reality, a mitochondrion experiences $\mathrm{Ca}^{2+}$ on the cytosolic side that could be significantly higher than the bulk $\left[\mathrm{Ca}^{2+}\right]_{\mathrm{C}}$. Furthermore, as shown below, the maximum flux through MCU estimated from the patch-clamp experiments on single mitoplasts comes out to be significantly larger. We would like to point out that the experiments in [19] investigated the function of MCU at the single mitoplast level, not the bioenergetics of the mitochondrion. Thus, we model bioenergetics at the single mitochondrion level as if it is residing inside a living cell, but the MCU functions the same way as it would in the mitoplast.

The maximum value of MCU current density $\left(\mathrm{I}_{\mathrm{MCU}} / \mathrm{C}_{\mathrm{m}}\right)$ observed in the patch-clamp experiments is equal to 206, 237, and $217 \mathrm{pA} / \mathrm{pF}$ in the case of WT, MICU1 KO, and MICU2 KO mitoplasts respectively at $\Delta \psi=-160 \mathrm{mV}$ [19]. These values can be used to estimate the maximum flux through $\mathrm{MCU}\left(V_{M C U, \max }\right.$ in Equation (3)) as follows:

$$
\mathrm{V}_{\mathrm{MCU}, \max }=\frac{\mathrm{I}_{\mathrm{MCU}}}{2 \times \mathrm{F} \times \mathrm{Vol}_{\mathrm{m}}}
$$


where $\mathrm{Vol}_{m}$ is the volume of the mitochondrion. We consider a spherical mitochondrion of radius $0.5 \mu \mathrm{m}$. Vais et al. [19] observed the mitoplast capacitance $\left(C_{m}\right)$ to be in the range $0.2-1 \mathrm{pF}$. We use $C_{m}=0.2 \mathrm{pF}$, giving $\mathrm{I}_{\mathrm{MCU}}=41.2,47.4$, and $43.4 \mathrm{pA}$ for WT, MICU1 KO, and MICU2 KO cells.

In intact cells, mitochondrial $\mathrm{Ca}^{2+}$ uptake at the single mitochondrion level also depends on the spatial distance between the ER and mitochondrion. $\mathrm{Ca}^{2+}$ is released from the ER through $\mathrm{IP}_{3} \mathrm{R}$ that diffuses away from the channel in the microdomain (Figure S4). We consider a single $\mathrm{IP}_{3} \mathrm{R}$, allowing it to open for $100 \mathrm{~ms}$, and model $\mathrm{Ca}^{2+}$ concentration in the microdomain $\left(\left[\mathrm{Ca}^{2+}\right]_{\text {mic }}\right)$ as a function of distance from the channel $(r)$ and current through $\mathrm{IP}_{3} \mathrm{R}\left(I_{I P 3 R}\right)$ using the following equation $[46,47]$ :

$$
\left[\mathrm{Ca}^{2+}\right]_{\mathrm{mic}}=\frac{\mathrm{I}_{\mathrm{IP} 3 \mathrm{R}}}{4 \pi \mathrm{rD} \mathrm{D}_{\mathrm{Ca}}} \exp ^{\left(-\frac{\mathrm{r}}{\lambda}\right)}+\left[\mathrm{Ca}^{2+}\right]_{\mathrm{rest}^{\prime}}
$$

where $I_{I P 3 R}=0.05 \mathrm{pA}[48],\left[\mathrm{Ca}^{2+}\right]_{\text {rest }}=100 \mathrm{nM}$, and $D_{C a}=223 \mu \mathrm{m}^{2} / \mathrm{s}$ [49] is the current flowing through an open $\mathrm{IP}_{3} \mathrm{R},\left[\mathrm{Ca}^{2+}\right]_{\mathrm{C}}$ at rest, and diffusion coefficient of $\mathrm{Ca}^{2+} . \lambda$ is given by

$$
\lambda=\sqrt{\frac{\mathrm{D}_{\mathrm{Ca}}}{\mathrm{k}_{\mathrm{on}} \mathrm{B}_{\mathrm{T}} \mathrm{K}_{\mathrm{d}} /\left(\mathrm{K}_{\mathrm{d}}+\mathrm{Ca}_{\text {rest }}\right)}}
$$

$B_{T}$ is the total concentration of $\mathrm{Ca}^{2+}$ binding protein with $K_{d}=2.0 \mu \mathrm{M}$ [50]. Figure S5 shows examples of $\mathrm{Ca}^{2+}$ concentration in the microdomain given by Equation (11) as a function of distance from the $\mathrm{IP}_{3} \mathrm{R}$ at different buffer concentrations.

Thus, the full model used for mitochondrial function at the single mitoplast level consists of Equations (7) (with Equations (3), (8) and (10)), (11), Equations (S1)-(S4). Equation (3) is multiplied by Equation (9) to incorporate the voltage dependence of $V_{M C U}$. We remove the parameter $\delta$ in Equation (7) for simulating the single mitoplast because $V_{M C U}$ in the whole-cell experiments was estimated based on the dynamics of extra-mitochondrial $\mathrm{Ca}^{2+}$ concentration, and we needed to factor-in the relative size of mitochondria with respect to the cytoplasm. In case of single mitoplast experiments, $V_{M C U}$ is estimated directly from the current flowing into the mitoplast through MCU and such factoring is not required.

Like the whole-cell model, the maximum flux through $\mathrm{Na}^{+} / \mathrm{Ca}^{2+}$ exchanger at the single mitoplast level is determined by fitting the resting value of $\left[\mathrm{Ca}^{2+}\right]_{\mathrm{M}}$ given by the model to the observed values (Figure S6). The values for $V_{\mathrm{NaCa} \text {,max }}$ in WT, MICU1 KO, and MICU2 $\mathrm{KO}$ are given in the legends of Figure S6. The fit results in a significantly large $V_{\mathrm{NaCa} \text {, max }}$ in MICU1 $\mathrm{KO}$ mitoplasts as compared to WT mitoplasts. This is in line with recent observations from whole-genome data from Alzheimer's disease patients where significant upregulation of genes encoding $\mathrm{Na}^{+} / \mathrm{Ca}^{2+}$ exchangers is observed when compared to age-matched healthy individuals (see also the Discussion section below) [51]. After reaching steady state during the first $100 \mathrm{~s}$ of simulations, the $\mathrm{IP}_{3} \mathrm{R}$ channel is allowed to open for $100 \mathrm{~ms}$. Typical time-traces of $\left[\mathrm{Ca}^{2+}\right]_{\mathrm{M}}, \Delta \psi,[\mathrm{NADH}]_{\mathrm{M}}$, and $[\mathrm{ATP}]_{\mathrm{M}}$ are shown in Figure $\mathrm{S6}$, where we consider a $24 \mathrm{~nm}$ wide microdomain [52]. A comparison between mitochondrial dynamics at the whole-cell (Figure S3) and single mitoplast (Figure S6) levels reveals four key differences. First, instead of hyperpolarization as in the case of whole-cell model, the $\mathrm{Ca}^{2+}$ uptake leads to the depolarization of IMM at the single mitoplast level (Figure S6B)-in line with the observations in Ref. [12]. Second, in the resting conditions, IMM in the MICU1 KO cells is more depolarized than WT and MICU2 KO cells, which is also consistent with observations [12]. Third, [ATP $]_{M}$ under resting conditions is lowest in MICU1 KO cells followed by MICU2 KO and WT cells (Figure S6D). Finally, the mitochondrial $\mathrm{Ca}^{2+}$ in MICU1 KO cells results in $[\mathrm{ATP}]_{\mathrm{M}}$ depletion due to the large depolarization that overshadows the rise in $[\mathrm{NADH}]_{\mathrm{M}}$ (Figure $\mathrm{S6C}$ ). Furthermore, the $\mathrm{Ca}^{2+}$ influx in MICU1 KO mitoplasts results in significantly large depolarization of IMM as compared to the other two conditions. As we discuss in the next section, this is also in line with recent observations [18].

Csordás et al. found that the average spatial width of the microdomain is $\sim 24 \mathrm{~nm}$ in RBL-2H3 cells [52]. However, significant variability exists in the microdomain width where its value can vary 
from a few nanometers to several hundred nanometers [53,54]. The resting and maximum values of $\left[\mathrm{Ca}^{2+}\right]_{\mathrm{M}}, \Delta \psi,[\mathrm{NADH}]_{\mathrm{M}}$, and $[\mathrm{ATP}]_{\mathrm{M}}$ from the model as we increase the width of the microdomain in WT, MICU1 KO, and MICU2 KO cells are shown in Figure 4. While the resting values (dotted lines) remain nearly unchanged, the maximum values (solid lines) of $\left[\mathrm{Ca}^{2+}\right]_{M}(\mathrm{~A}), \Delta \psi(B),[N A D H]_{M}(C)$, and $[\mathrm{ATP}]_{\mathrm{M}}(\mathrm{D})$ in WT and MICU2 KO cells decrease significantly as we increase the width of the microdomain. This occurs because the mitochondrion is exposed to lower extra-mitochondrial $\mathrm{Ca}^{2+}$ concentration as we increase the width of the microdomain (longer distance between the $\mathrm{IP}_{3} \mathrm{R}$ and $\mathrm{MCU})$. However, the decrease in the maximum values of the four variables is not as dramatic in the MICU1 KO mitoplast, even if we consider the microdomain to be a few hundred nanometers wide. Furthermore, the change in $[\mathrm{ATP}]_{\mathrm{M}}$ in MICU1 $\mathrm{KO}$ cells is significantly lower in addition to the fact that $[\mathrm{ATP}]_{\mathrm{M}}$ decreases in response to $\left[\mathrm{Ca}^{2+}\right]_{C}$ rise (note that the "maximum" value of $[\mathrm{ATP}]_{\mathrm{M}}$ after the channel opens is smaller than the resting value).
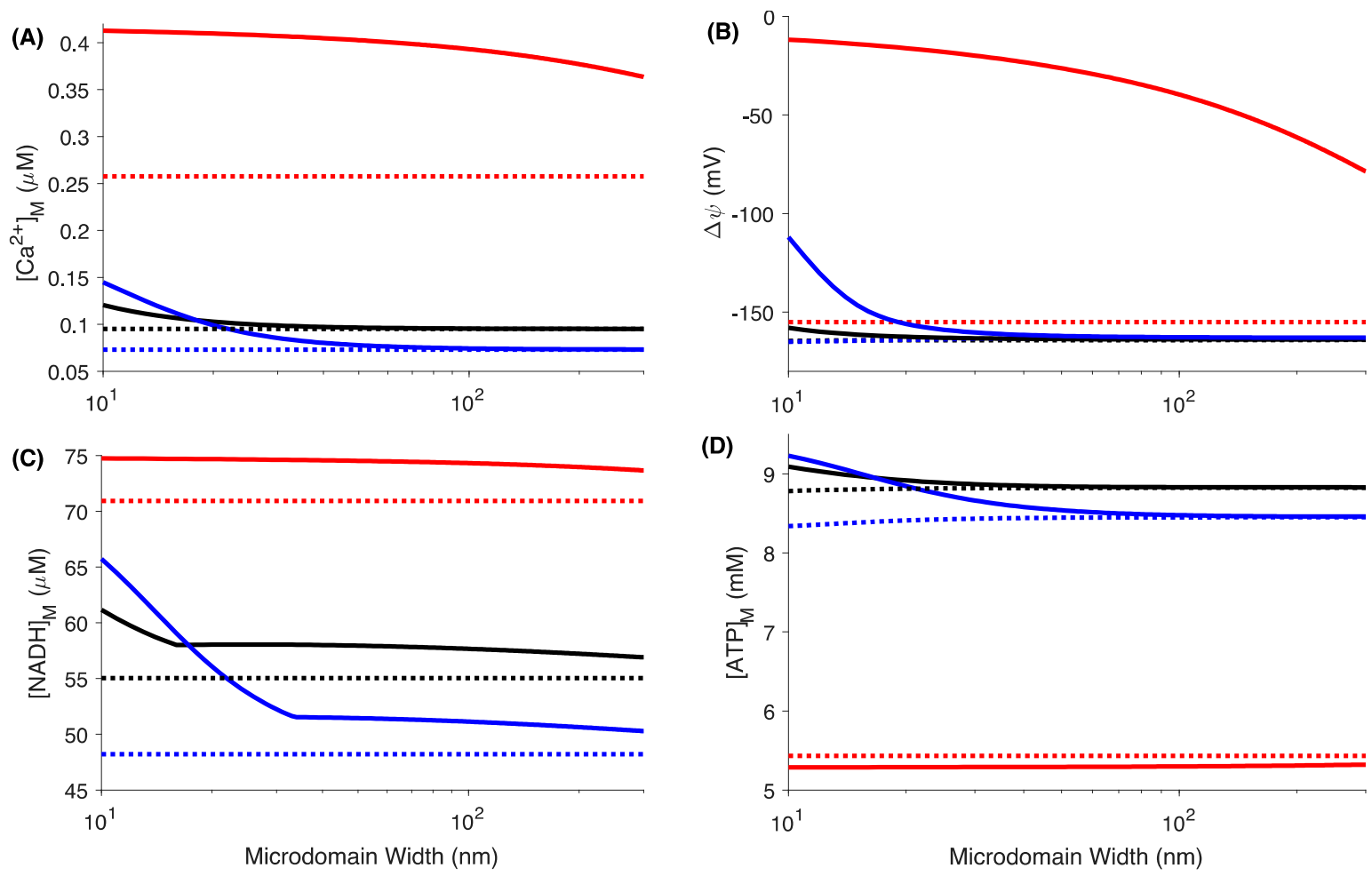

Figure 4. Changes in mitochondrial variables in response to the opening of a single $\mathrm{IP}_{3} \mathrm{R}$ channel at the single mitochondrion level. A single $\mathrm{IP}_{3} \mathrm{R}$ residing in the ER membrane is allowed to open for $100 \mathrm{~ms}$ starting at $100 \mathrm{~s}$, and the maximum changes in different mitochondrial variables are recorded. The resting value (dotted lines) and the maximum value after the channel opens (solid lines) of $\left[\mathrm{Ca}^{2+}\right]_{\mathrm{M}}$ (A), $\Delta \psi(\mathbf{B}),[\mathrm{NADH}]_{\mathrm{M}}(\mathbf{C}),[\mathrm{ATP}]_{\mathrm{M}}$, and (D) in WT (black lines), MICU1 KO (red lines), and MICU2 $\mathrm{KO}$ cells (blue lines). Parameters used in the simulations are the same as given in the text. The value of $V_{\mathrm{NaCa}, \max }$ given by the model is $1.112,1838.6$, and $35.9675 \mu \mathrm{M} / \mathrm{s}$.

We repeat the simulations in Figure $\mathrm{S} 6$ varying the duration for which the $\mathrm{IP}_{3} \mathrm{R}$ channel is open and analyze the changes in the mitochondrial variables as $\left[\mathrm{Ca}^{2+}\right]_{\text {mic }}$ rises. As is clear from Figure 5, the change in $\left[\mathrm{Ca}^{2+}\right]_{\mathrm{M}}$ (Figure $\left.5 \mathrm{~A}\right), \Delta \psi$ (Figure $\left.5 \mathrm{~B}\right),[\mathrm{NADH}]_{\mathrm{M}}$ (Figure $5 \mathrm{C}$ ), and $[\mathrm{ATP}]_{\mathrm{M}}$ (Figure 5D) with respect to their resting values gets larger as we increase the open duration of the channel from $10 \mathrm{~ms}$ to $1 \mathrm{~s}$ incrementally. The larger mitochondrial $\mathrm{Ca}^{2+}$ uptake in MICU1 $\mathrm{KO}$ cells results in larger depolarization of IMM than MICU2 KO and WT cells (Figure 5B). Interestingly, the relative change in $[\mathrm{NADH}]_{\mathrm{M}}$ in MICU1 KO mitoplasts is smaller than both WT and MICU2 KO cells despite the larger mitochondrial $\mathrm{Ca}^{2+}$ influx (Figure $5 \mathrm{C}$ ). 

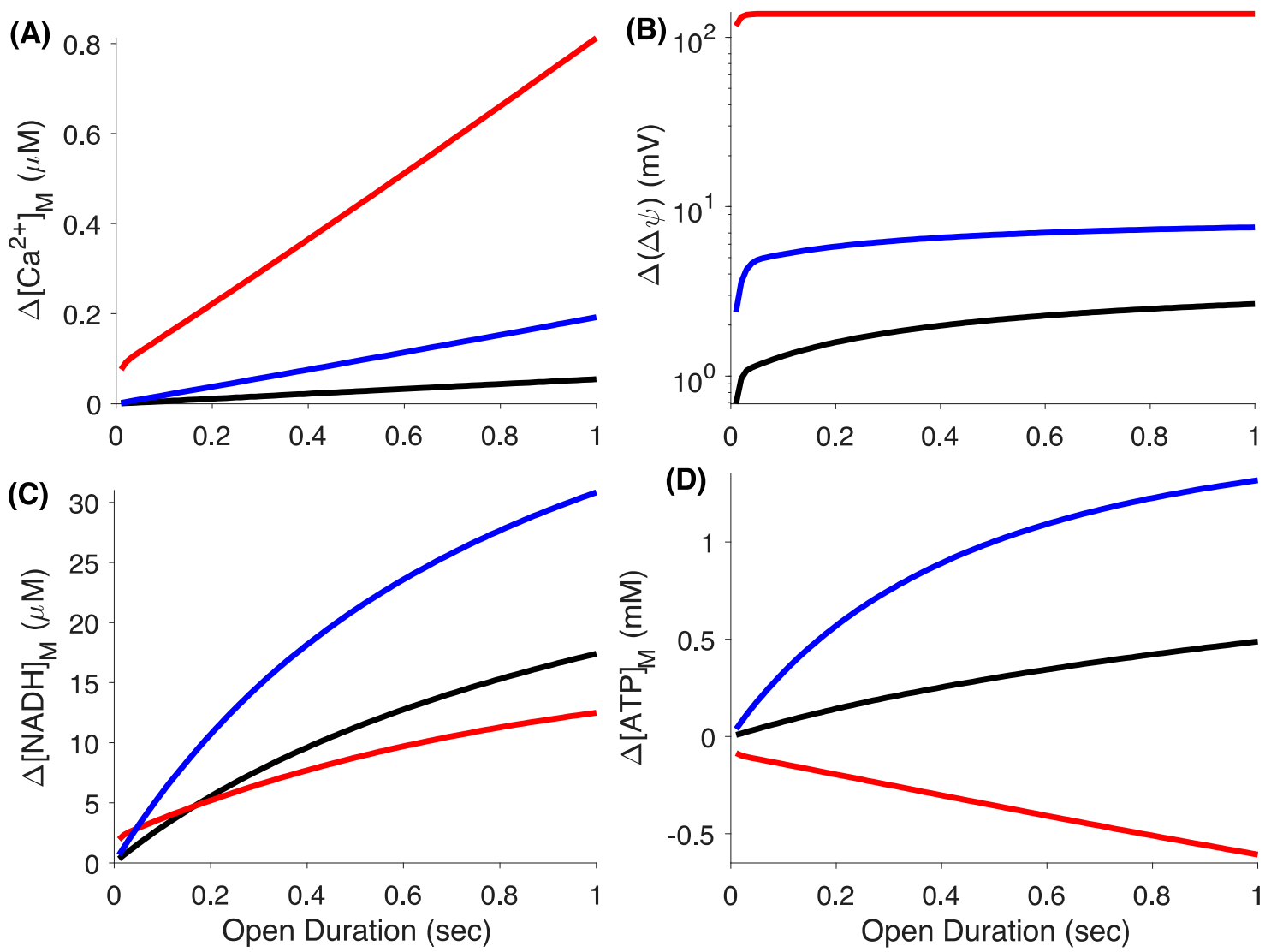

Figure 5. Relative changes in mitochondrial variables in response to the opening of a single $\mathrm{IP}_{3} \mathrm{R}$ channel at the single mitochondrion level. A single $\mathrm{IP}_{3} \mathrm{R}$ residing in the ER membrane is allowed to open for a given duration ( $x$-axes) starting at $100 \mathrm{~s}$ and the optimal changes with respect to the resting values of different mitochondrial variables are recorded (see Figure S6) and shown along $y$-axes. The change in $\left[\mathrm{Ca}^{2+}\right]_{\mathrm{M}}(\mathbf{A}), \Delta \psi(\mathbf{B}),[\mathrm{NADH}]_{\mathrm{M}}(\mathbf{C})$, and $[\mathrm{ATP}]_{\mathrm{M}}(\mathbf{D})$. A $24 \mathrm{~nm}$ wide microdomain is considered in these simulations.

To investigate this counterintuitive result further, we look at the three fluxes that control $[\mathrm{NADH}]_{\mathrm{M}}$ in the model (Equation (S1)). As expected, the pyruvate dehydrogenase-catalyzed reaction (Equation (S8)) leading to NADH production increases with $\left[\mathrm{Ca}^{2+}\right]_{\mathrm{M}}$ (Figure S7A) $[55,56]$. However, the resting $\left[\mathrm{Ca}^{2+}\right]_{\mathrm{M}}$ in MICU1 KO cells $(\sim 0.258 \mu \mathrm{M})$ is in the range where the reaction is almost saturated already and any further increase in $\left[\mathrm{Ca}^{2+}\right]_{\mathrm{M}}$ would lead to little change in this reaction. The second contribution to $[\mathrm{NADH}]_{\mathrm{M}}$ in the model comes from the malate-aspartate shuttle (MAS) $[57,58]$. The model takes into account the activation of two mammalian carriers aralar and citrin involved in MAS by moderate cytosolic $\mathrm{Ca}^{2+}$ increases (Equation (S9)). By activating the Krebs cycle, the rise in $\left[\mathrm{Ca}^{2+}\right]_{\mathrm{M}}$ would lead to a decrease in the amount of $\alpha$-ketoglutarate, a key-metabolite of the MAS [57,58]. This limiting step is taken into account in the model [36] and the flux due to MAS shuttle decreases with $\left[\mathrm{Ca}^{2+}\right]_{\mathrm{M}}$ and is almost at the minimum value in MICU1 KO cells (Figure S7B) where the resting $\left[\mathrm{Ca}^{2+}\right]_{\mathrm{M}} \sim 0.26 \mu \mathrm{M}$ (Figure S6A). Finally, in the model, the oxidation of NADH in the Electron Transport Chain and the coupled extrusion of protons from the mitochondria are incorporated in a single equation (Equation (S10)) [36,38,59-63]. This flux declines for more hyperpolarized IMM, since it is difficult to pump protons against a large potential gradient and vice versa (Figure S7C). The relatively more depolarized IMM in resting state in MICU1 KO cells results in a larger value of this flux that decreases $[\mathrm{NADH}]_{\mathrm{M}}$ further.

The large increase in $[\mathrm{NADH}]_{\mathrm{M}}$ due to the rise in $\left[\mathrm{Ca}^{2+}\right]_{\mathrm{M}}$ in WT and MICU2 KO mitoplasts results in a significant increase in $[\mathrm{ATP}]_{\mathrm{M}}$ which increases further as the open duration of the channel increases (Figure 5D). Contrary to WT and MICU2 KO, the large depolarization of the IMM coupled 
with a relatively small increase in $[\mathrm{NADH}]_{\mathrm{M}}$ in MICU1 KO cells leads to a drop in $[\mathrm{ATP}]_{\mathrm{M}}$. The larger resting value of $[\mathrm{NADH}]_{\mathrm{M}}$ and smaller increase in response to cytosolic $\mathrm{Ca}^{2+}$ in MICU1 KO cells is consistent with observations where a larger concentration of NADH in resting state and smaller change in response to Histamine-induced rise in intracellular $\mathrm{Ca}^{2+}$ was observed in primary fibroblasts with MICU1 mutations in individuals with a disease phenotype characterized by proximal myopathy, learning difficulties, and a progressive extrapyramidal movement disorder as compared to those from age-matched healthy individuals [28]. The difference between the changes in $[\mathrm{NADH}]_{\mathrm{M}}$ and $[\mathrm{ATP}]_{\mathrm{M}}$ in MICU1 KO mitoplasts with respect to WT cells grow as we increase the open duration of $\mathrm{IP}_{3} \mathrm{R}$, indicating that, in the face of prolonged $\left[\mathrm{Ca}^{2+}\right]_{\mathrm{C}}$ increases, MICU1 $\mathrm{KO}$ cells would be more vulnerable to damage due to the lack of ATP to perform necessary cell functions.

To test whether adding $\mathrm{Ca}^{2+}$ buffer to the cytoplasm would restore mitochondrial function in MICU1 KO cells, we vary the buffer concentration from 0 to $1000 \mu \mathrm{M}$. Like the results shown in Figure 4, the peak value of $\left[\mathrm{Ca}^{2+}\right]_{\mathrm{M}}$ decreases significantly in WT and MICU2 KO cells as we increase the buffer concentration (Figure S8). However, both the maximum and resting values of $\left[\mathrm{Ca}^{2+}\right]_{M}$ in MICU1 KO cells remain nearly constant. The values of other variables follow the same trend and are not shown. We remark that the kinetics of the buffer used in these simulations are relatively slow. A high concentration of a buffer with significantly faster kinetics that could immediately uptake most of the $\mathrm{Ca}^{2+}$ released by $\mathrm{IP}_{3} \mathrm{R}$ before it reaches the mitochondrion would decrease the peak value of $\left[\mathrm{Ca}^{2+}\right]_{\mathrm{M}}$ (Figure S9). Nevertheless, the resting values of $\left[\mathrm{Ca}^{2+}\right]_{\mathrm{M}},[\mathrm{ATP}]_{\mathrm{M}}$, and other variables remain unchanged from those shown in Figure S8 (dashed lines in Figure S9).

\section{Discussion}

While the sigmoidal dependence of mitochondrial $\mathrm{Ca}^{2+}$ uptake on cytosolic $\mathrm{Ca}^{2+}$ was observed 60 years ago [64,65], details about how MICU1, MICU2, and EMRE define this relationship by regulating the gating of MCU began to emerge recently $[8,66]$. The functional importance of these regulatory proteins is further highlighted by their crucial role in various pathologies [27-32]. A key challenge for future experiments is to investigate how these regulatory proteins modulate mitochondrial $\mathrm{Ca}^{2+}$ influx through MCU in intact cells under physiological and pathological conditions, and how the interaction between MCU and regulatory proteins affects the bioenergetics of mitochondria in particular and cell signaling in general. This task is further complicated by the fact that mitochondrial $\mathrm{Ca}^{2+}$ uptake depends on the mitochondrial organization in the cell, the size of individual mitochondrion, the spatial positioning of a single mitochondrion with respect to other $\mathrm{Ca}^{2+}$-releasing organelles and channels, and various $\mathrm{Ca}^{2+}$ buffering proteins inside and outside the mitochondria. To make matters worse, mitochondria are in a constant state of transporting, fission, fusion, and fragmentation as the local $\mathrm{Ca}^{2+}$ gradients and metabolic demands change dynamically during cell functioning. Existing experimental techniques are not equipped to address the majority of these and other related issues. Data-driven computational models closely reproducing key observations about MCU function and its dependence on various variables and modulators offer a viable alternative.

Several models for mitochondrial $\mathrm{Ca}^{2+}$ signaling have been developed over the past (for example, see $[36,38,47,59,61-63,67-70])$. However, they are mostly based on $\mathrm{Ca}^{2+}$ uptake in permeabilized cell cultures or isolated mitochondria suspended in aqueous solutions. These models do not properly incorporate the fine details of MCU's gating kinetics, which could lead to erroneous conclusions [70]. The model in [71] links the biophysical properties of MCU activity to the mitochondrial $\mathrm{Ca}^{2+}$ uptake at the whole-cell level using Michaelis-Menten type relationship, but it does not incorporate the regulation of MCU by MICU1, MICU2, or EMRE. Similarly, the model in [72] investigates the mitochondrial $\mathrm{Ca}^{2+}$ dynamics in cells and isolated mitochondria in suspensions, but does not incorporate the effects of these proteins. Our model not only reproduces many key observations about MCU function at the single mitochondrion and whole-cell levels but also incorporates the role of mitochondrial membrane potential, MICU1, MICU2, and EMRE at both scales. Our analysis reaffirms that the three regulatory proteins together with MMP, the spatial positioning of the mitochondria with respect to the 
$\mathrm{Ca}^{2+}$ releasing channels or organelles, and the spatiotemporal dynamics of $\mathrm{Ca}^{2+}$ concentration and buffering proteins make for a robust and sophisticated signaling machinery for regulating mitochondrial metabolic function.

Our model provides an excellent platform for investigating several of the issues outlined above. As an example, we investigate the interaction of a single $\mathrm{IP}_{3} \mathrm{R}$ with $\mathrm{MCU}$ in a microdomain and show that the separation between the two channels, the concentration of $\mathrm{Ca}^{2+}$ buffer in the microdomain, the open duration of $\mathrm{IP}_{3} \mathrm{R}$, and the regulatory proteins all play key roles in mitochondrial metabolic function. Interestingly, our microdomain model shows that, while $\mathrm{Ca}^{2+}$ release through $\mathrm{IP}_{3} \mathrm{R}$ results in an increased ATP in WT and MICU2 KO mitoplasts, the exaggerated $\mathrm{Ca}^{2+}$ uptake in MICU1 $\mathrm{KO}$ mitochondrion results in a significant drop in ATP. The rise in ATP and $\left[\mathrm{Ca}^{2+}\right]_{\mathrm{M}}$ in response to the opening of $\mathrm{IP}_{3} \mathrm{R}$ in WT and MICU2 KO conditions decreases as we increase the width of the microdomain within the experimentally observed range or increase the concentration of $\mathrm{Ca}^{2+}$ buffer. Both of these parameters do not affect the metabolism of MICU1 KO mitochondria. A high concentration of fast buffers is needed to prevent the mitochondrial $\mathrm{Ca}^{2+}$ overload in MICU1 KO cells.

Increasing the open duration of $\mathrm{IP}_{3} \mathrm{R}$ also has an opposite effect in WT (and MICU2 KO) and MICU1 $\mathrm{KO}$ mitochondria where we observe an increasingly positive and negative change in ATP, respectively. These results are in line with reports claiming that the human loss-of-function mutations in MICU1 results in early-onset neuromuscular weakness, impaired cognition, extrapyramidal motor disorder, and perinatal lethality [27-31] through mitochondrial $\mathrm{Ca}^{2+}$ overload and impaired bioenergetics [27]. The model also leads to two key observations that warrant further discussion. First, the $\mathrm{Ca}^{2+}$ influx in MICU1 KO mitoplasts results in significantly larger depolarization of IMM. This is in line with recent observations [18]. Specifically, HEK293 cells expressing two mutant MCU channels individually were exposed to repeated 5 to $7 \mu \mathrm{M}$ boluses of cytosolic $\mathrm{Ca}^{2+}$ that were $150 \mathrm{~s}$ apart. While mitochondria expressing WT MCU rapidly took up $\mathrm{Ca}^{2+}$ in response to 9-12 successive boluses, those in cells expressing mutant MCU failed to take up $\mathrm{Ca}^{2+}$ after only two boluses and exhibited a complete loss of IMM potential. Interestingly, both mutants used in these experiments results in the loss of matrix $\mathrm{Ca}^{2+}$-mediated gatekeeping (inhibition) like MICU1 KO.

Another key observation from the model is the significantly larger $V_{\mathrm{NaCa}, \max }$ in MICU1 KO mitochondria as compared to WT. This came out naturally from the fit as the $\mathrm{Na}^{+} / \mathrm{Ca}^{2+}$ exchangers have to compensate for larger $\mathrm{Ca}^{2+}$ influx in MICU1 KO mitochondria under resting conditions. Remarkably, a recent analysis of mitochondrial $\mathrm{Ca}^{2+}$-related genes in 25 publicly available microarray and RNA-Sequencing datasets revealed a significant upregulation of $\mathrm{Na}^{+} / \mathrm{Ca}^{2+}$ exchanger-encoding gene SLC8B1 in Alzheimer's disease patients when compared to age-matched healthy individuals [51]. The authors attributed this to the counteracting effect in the diseased human brain to avoid mitochondrial $\mathrm{Ca}^{2+}$ overload. Along these lines, upregulating the expression level of SLC8B1 gene rescued mitochondrial $\mathrm{Ca}^{2+}$-induced pathology in 3xTg Alzheimer's disease mouse model [73].

Given that kinetic data on the single channel function of MCU is slowly emerging [5,6,11,74], our model is formulated so that such future observations can be incorporated. For example, if time traces representing the gating state of $\mathrm{MCU}$ as a function of time is available, one can extract the transition rates between different states by fitting the following log-Likelihood function to the traces (see [34,75] for details):

$$
\log \left(\begin{array}{c}
\log \left(\mathrm{f}_{\mathrm{C}}\left(\mathrm{tc}_{1}, \mathrm{to}_{1}, \mathrm{tc}_{2}, \mathrm{to}_{2}, \ldots \ldots \mathrm{tc}_{\mathrm{n}}, \mathrm{to}_{\mathrm{n}}\right)\right)= \\
\exp \left(\mathrm{Q}_{\mathrm{CC}} \mathrm{tc}_{1}\right) \mathrm{Q}_{\mathrm{CO}} \exp \left(\mathrm{Q}_{\mathrm{OO}} \mathrm{to}_{1}\right) \mathrm{Q}_{\mathrm{OC}} \exp \left(\mathrm{Q}_{\mathrm{CC}} \mathrm{tc}_{2}\right) \mathrm{Q}_{\mathrm{CO}} \exp \left(\mathrm{Q}_{\mathrm{OO}} \mathrm{to}_{2}\right) \ldots \\
\exp \left(\mathrm{Q}_{\mathrm{OO}} \mathrm{to}_{\mathrm{n}}\right) \mathrm{u}_{\mathrm{O}}
\end{array}\right),
$$

where $\pi_{C}$ is a vector of the initial probabilities of all close states being occupied at equilibrium, $t o_{i}$ and $t c_{i}$ are the $i t h$ open and close times in the time series, respectively, $u_{O}$ is a vector of all ones with length equal to the number of open states in the model, and $Q_{O C}$ is a $(2 \times 6)$ matrix of the transition rates from all open to all close states, etc. 
Alternatively, if the distributions of dwell-times in open or close states are available, one can extract the transition rates by fitting the following functions to such distributions, respectively [34,75]:

$$
\begin{aligned}
& \mathrm{f}_{\mathrm{O}}\left(\mathrm{t}_{\mathrm{O}}\right)=\pi_{\mathrm{O}} \exp \left(\mathrm{Q}_{\mathrm{OO}} \mathrm{t}_{\mathrm{O}}\right) \mathrm{Q}_{\mathrm{OC}} \mathrm{u}_{\mathrm{C}}, \\
& \mathrm{f}_{\mathrm{C}}\left(\mathrm{t}_{\mathrm{C}}\right)=\pi_{\mathrm{C}} \exp \left(\mathrm{Q}_{\mathrm{CC}} \mathrm{t}_{\mathrm{C}}\right) \mathrm{Q}_{\mathrm{CO}} \mathrm{u}_{\mathrm{O}} .
\end{aligned}
$$

where $\pi_{O}$ is a vector of initial probabilities of all open states being occupied at equilibrium, $u_{C}$ is a vector of all ones with length equal to the number of close states in the model, $Q_{C O}$ is a $(6 \times 2)$ matrix of the transition rates from all close to all open states, and $Q_{C C}$ is a $(6 \times 6)$ matrix of the transition rates from all close to all close states etc.

As a toy example, we used the double-exponential behavior of open dwell-time histogram observed in [11]. Specifically, in these experiments, MCU and the regulatory proteins were inserted into a planar bilayer membrane and electrophysiological recording of single channel activity was carried out. In one of these experiments (Figure S3B in [11]), the open dwell-time distribution could be fitted with double exponential with time constants $\tau_{1}=12.06 \mathrm{~ms}$ and $\tau_{2}=161.92 \mathrm{~ms}$. We used these time constants to generate experimental dwell-time distribution (green bars in Figure 6A) and fit Equation (14) to it. The model fit to the data is shown by the dashed line in Figure 6A. The transition rates between different states from the fit are given in section "Extracting single channel gating parameters from dwell-time distributions" of the Supplementary Information Text. The rates obtained from the fit are then used to stochastically simulate the gating of single MCU channel at different $\left[\mathrm{Ca}^{2+}\right]_{\mathrm{C}}$ and $\left[\mathrm{Ca}^{2+}\right]_{\mathrm{M}}$ values using the method previously developed $[35,76,77]$. Consistent with the results at the whole-cell and single mitochondrion levels, the single channel activity of MCU increases progressively as we increase $\left[\mathrm{Ca}^{2+}\right]_{C}$ (Figure $6 \mathrm{~B}, \mathrm{C}$ ). Furthermore, the frequency of the channel visiting the open states in general, and $\mathrm{O}_{44}$ state in particular increases significantly as we increase $\left[\mathrm{Ca}^{2+}\right]_{\mathrm{M}}$ from $0.4 \mu \mathrm{M}$ (Figure 6B) to $1 \mu \mathrm{M}$ (Figure 6C).

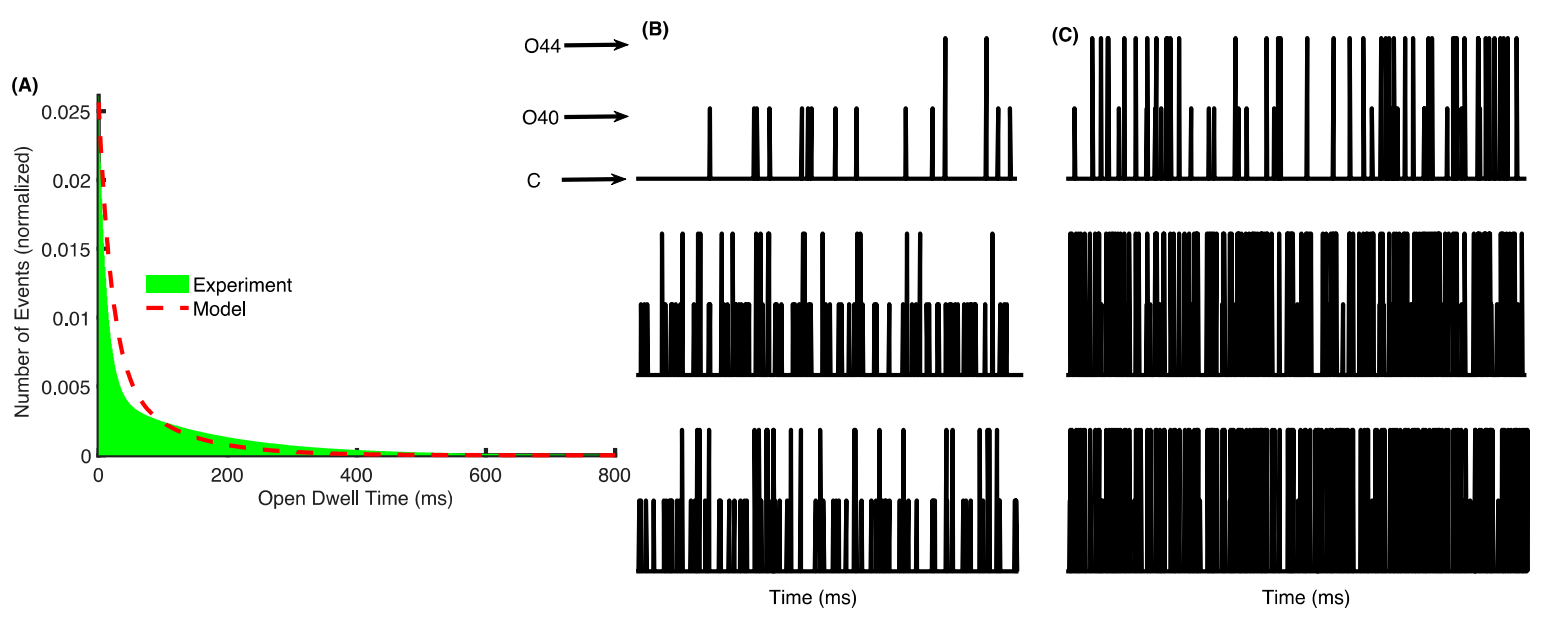

Figure 6. Extracting single channel kinetic parameters by fitting to the open dwell-time distribution. (A) Open dwell-time distribution generated using the time constants $\left(\tau_{1}=12.06 \mathrm{~ms}\right.$ and $\left.\tau_{2}=161.92 \mathrm{~ms}\right)$ observed in lipid bilayer experiments [11] (green bars) and model fit (dashed line); (B) time traces from the model using the transition rates obtained from the model at $\left[\mathrm{Ca}^{2+}\right]_{\mathrm{M}}=0.4 \mu \mathrm{M}$ and $\left[\mathrm{Ca}^{2+}\right]_{\mathrm{C}}=1 \mu \mathrm{M}$ (top panel), $10 \mu \mathrm{M}$ (middle panel), and $100 \mu \mathrm{M}$ (bottom panel); (C) same as in (B) but at $\left[\mathrm{Ca}^{2+}\right]_{\mathrm{M}}=1 \mu \mathrm{M}$.

\section{Conclusions}

Mitochondrial $\mathrm{Ca}^{2+}$ overload either due to MICU1 mutations [27-31], MCU upregulation [51], or impaired function of $\mathrm{Na}^{+} / \mathrm{Ca}^{2+}$ exchangers [73] plays a causal role in various diseases. For example, recent observations show that it not only contributes to the progression of disease but also precedes neuropathology in different animal models of Alzheimer's disease [51,73]. Mitochondrial $\mathrm{Ca}^{2+}$ 
overload was shown to accelerate memory decline, amyloidosis, and tau pathology by promoting the production of reactive oxygen species, metabolic dysfunction, and upregulation of $\beta$ secretase expression, and neurodegeneration [51,73]. Furthermore, preventing mitochondrial $\mathrm{Ca}^{2+}$ overload was proven sufficient to impede Alzheimer's disease-associated pathology and memory loss [51,73]. A data-driven model such as ours will help understand the role of different mechanisms regulating mitochondrial $\mathrm{Ca}^{2+}$ uptake in Alzheimer's disease and many other diseases where mitochondrial $\mathrm{Ca}^{2+}$ overload is believed to play a major role $[78,79]$. Our model not only incorporates several key observations about MCU function under WT, MICU1 KO, and MICU2 KO conditions at the whole-cell and single mitochondrion levels, but also leaves room for incorporating future observations and providing information about experimentally inaccessible parameters at the single MCU level such as the transition rates between different conducting states of the channel, etc.

Supplementary Materials: The following are available online at http://www.mdpi.com/2073-4409/9/6/1520/s1. Supplementary Methods (Equations (S1)-(S15)); Figure S1: Using a different set of parameters to fit the model the MCU Ca ${ }^{2+}$ uptake rate in MICU2 KO cell cultures, Figure S2: Considering the state with two and one $\mathrm{Ca}^{2+}$ bound to MICU1 and MICU2 respectively to be an open state results in higher $\mathrm{Ca}^{2+}$ uptake rate at low $\left[\mathrm{Ca}^{2+}\right]_{C}$, Figure S3: Changes in mitochondrial variables in response to a step-like increase in $\left[\mathrm{Ca}^{2+}\right]_{\mathrm{C}}$ at the whole-cell level, Figure S4: Schematic of the mitochondrial $\mathrm{Ca}^{2+}$ uptake model at the single mitochondrion level, Figure S5: $\mathrm{Ca}^{2+}$ concentration in the microdomain $\left(\left[\mathrm{Ca}^{2+}\right]_{\text {mic }}\right)$ due to the opening of a single $\mathrm{IP}_{3} \mathrm{R}$ as a function of distance from the channel, Figure S6: Changes in mitochondrial variables in response to the opening of a single $\mathrm{IP}_{3} \mathrm{R}$ channel at the single mitoplast level, Figure S7: The behavior of the three reactions controlling $[\mathrm{NADH}]_{\mathrm{M}}$, Figure S8: Changes in $\left[\mathrm{Ca}^{2+}\right]_{\mathrm{M}}$ in response to the opening of a single $\mathrm{IP}_{3} \mathrm{R}$ channel at the single mitochondrion level as we vary the concentration of $\mathrm{Ca}^{2+}$ buffer in the cytoplasm, Figure S9: Changes in $\left[\mathrm{Ca}^{2+}\right]_{\mathrm{M}}$ and $[\mathrm{ATP}]_{\mathrm{M}}$ in response to the opening of a single $\mathrm{IP}_{3} \mathrm{R}$ channel at the single mitochondrion level as we vary the concentration of $\mathrm{Ca}^{2+}$ buffer in the cytoplasm in MICU1 KO cells, Table S1: Meaning and values of various parameters used in the bioenergetics model., Table S2: Values of various parameters given by the fit of the kinetic model for MCU function to the observed open probability of MCU as a function of $\left[\mathrm{Ca}^{2+}\right]_{\mathrm{C}}$ and $\left[\mathrm{Ca}^{2+}\right]_{\mathrm{M}}$, Table S3: Values of various probability flux parameters given by the fitting the model to open dwell-time distribution of MCU.

Author Contributions: Conceptualization, G.U.; methodology, G.U. and S.I.S.; software, G.U. and S.I.S.; validation, G.U. and S.I.S.; formal analysis, G.U. and S.I.S.; investigation, G.U. and S.I.S.; resources, G.U.; data curation, G.U. and S.I.S.; writing - original draft preparation, G.U. and S.I.S.; writing—review and editing, G.U.; visualization, S.I.S.; supervision, G.U.; project administration, G.U.; funding acquisition, G.U. All authors have read and agreed to the published version of the manuscript.

Funding: This research was funded by National Institute of Health, grant number R01 AG053988 (to G.U.).

Conflicts of Interest: The authors declare no conflict of interest. The funders had no role in the design of the study; in the collection, analyses, or interpretation of data; in the writing of the manuscript, or in the decision to publish the results.

\section{References}

1. Rizzuto, R.; De Stefani, D.; Raffaello, A.; Mammucari, C. Mitochondria as sensors and regulators of calcium signalling. Nat. Rev. Mol. Cell Biol. 2012, 13, 566. [CrossRef]

2. Szabadkai, G.; Duchen, M.R. Mitochondria: The hub of cellular $\mathrm{Ca}^{2+}$ signaling. Physiology 2008, $23,84-94$. [CrossRef]

3. McCormack, J.G.; Halestrap, A.P.; Denton, R.M. Role of calcium ions in regulation of mammalian intramitochondrial metabolism. Physiol. Rev. 1990, 70, 391-425. [CrossRef]

4. Gunter, K.K.; Gunter, T.E. Transport of calcium by mitochondria. J. Bioenerg. Biomembr. 1994, 26, 471-485. [CrossRef] [PubMed]

5. De Stefani, D.; Raffaello, A.; Teardo, E.; Szabò, I.; Rizzuto, R. A forty-kilodalton protein of the inner membrane is the mitochondrial calcium uniporter. Nature 2011, 476, 336. [CrossRef] [PubMed]

6. Kirichok, Y.; Krapivinsky, G.; Clapham, D.E. The mitochondrial calcium uniporter is a highly selective ion channel. Nature 2004, 427, 360. [CrossRef] [PubMed]

7. Patron, M.; Raffaello, A.; Granatiero, V.; Tosatto, A.; Merli, G.; De Stefani, D.; Wright, L.; Pallafacchina, G.; Terrin, A.; Mammucari, C. The mitochondrial calcium uniporter (MCU): Molecular identity and physiological roles. J. Biol. Chem. 2013, 288, 10750-10758. [CrossRef] 
8. Foskett, J.K.; Philipson, B. The mitochondrial $\mathrm{Ca}^{2+}$ uniporter complex. J. Mol. Cell. Cardiol. 2015, 78, 3-8. [CrossRef]

9. Baughman, J.M.; Perocchi, F.; Girgis, H.S.; Plovanich, M.; Belcher-Timme, C.A.; Sancak, Y.; Bao, X.R.; Strittmatter, L.; Goldberger, O.; Bogorad, R.L. Integrative genomics identifies MCU as an essential component of the mitochondrial calcium uniporter. Nature 2011, 476, 341. [CrossRef]

10. Perocchi, F.; Gohil, V.M.; Girgis, H.S.; Bao, X.R.; McCombs, J.E.; Palmer, A.E.; Mootha, V.K. MICU1 encodes a mitochondrial EF hand protein required for $\mathrm{Ca}^{2+}$ uptake. Nature 2010, 467, 291. [CrossRef]

11. Patron, M.; Checchetto, V.; Raffaello, A.; Teardo, E.; Reane, D.V.; Mantoan, M.; Granatiero, V.; Szabò, I.; De Stefani, D.; Rizzuto, R. MICU1 and MICU2 finely tune the mitochondrial $\mathrm{Ca}^{2+}$ uniporter by exerting opposite effects on MCU activity. Mol. Cell 2014, 53, 726-737. [CrossRef] [PubMed]

12. Payne, R.; Hoff, H.; Roskowski, A.; Foskett, J.K. MICU2 restricts spatial crosstalk between InsP3R and MCU channels by regulating threshold and gain of MICU1-mediated inhibition and activation of MCU. Cell Rep. 2017, 21, 3141-3154. [CrossRef] [PubMed]

13. Plovanich, M.; Bogorad, R.L.; Sancak, Y.; Kamer, K.J.; Strittmatter, L.; Li, A.A.; Girgis, H.S.; Kuchimanchi, S.; De Groot, J.; Speciner, L. MICU2, a paralog of MICU1, resides within the mitochondrial uniporter complex to regulate calcium handling. PLoS ONE 2013, 8, e55785. [CrossRef] [PubMed]

14. Patron, M.; Granatiero, V.; Espino, J.; Rizzuto, R.; De Stefani, D. MICU3 is a tissue-specific enhancer of mitochondrial calcium uptake. Cell Death Differ. 2019, 26, 179. [CrossRef] [PubMed]

15. Mallilankaraman, K.; Cárdenas, C.; Doonan, P.J.; Chandramoorthy, H.C.; Irrinki, K.M.; Golenár, T.; Csordás, G.; Madireddi, P.; Yang, J.; Müller, M. MCUR1 is an essential component of mitochondrial $\mathrm{Ca}^{2+}$ uptake that regulates cellular metabolism. Nat. Cell Biol. 2012, 14, 1336. [CrossRef] [PubMed]

16. Sancak, Y.; Markhard, A.L.; Kitami, T.; Kovács-Bogdán, E.; Kamer, K.J.; Udeshi, N.D.; Carr, S.A.; Chaudhuri, D.; Clapham, D.E.; Li, A.A. EMRE is an essential component of the mitochondrial calcium uniporter complex. Science 2013, 342, 1379-1382. [CrossRef]

17. Payne, R.; Li, C.; Foskett, J.K. Variable Assembly of EMRE and MCU Creates Functional Channels with Distinct Gatekeeping Profiles. iScience 2020, 23, 101037. [CrossRef]

18. Vais, H.; Payne, R.; Li, C.; Foskett, J.K. Strongly coupled transmembrane mechanisms control MCU-mediated mitochondrial $\mathrm{Ca}^{2+}$ uptake. bioRxiv 2020. [CrossRef]

19. Vais, H.; Mallilankaraman, K.; Mak, D.-O.D.; Hoff, H.; Payne, R.; Tanis, J.E.; Foskett, J.K. EMRE is a matrix $\mathrm{Ca}^{2+}$ sensor that governs gatekeeping of the mitochondrial $\mathrm{Ca}^{2+}$ uniporter. Cell Rep. 2016, 14, 403-410. [CrossRef]

20. Csordás, G.; Golenár, T.; Seifert, E.L.; Kamer, K.J.; Sancak, Y.; Perocchi, F.; Moffat, C.; Weaver, D.; de la Fuente Perez, S.; Bogorad, R. MICU1 controls both the threshold and cooperative activation of the mitochondrial $\mathrm{Ca}^{2+}$ uniporter. Cell Metab. 2013, 17, 976-987. [CrossRef]

21. Xing, Y.; Wang, M.; Wang, J.; Nie, Z.; Wu, G.; Yang, X.; Shen, Y. Dimerization of MICU Proteins Controls Ca ${ }^{2+}$ Influx through the Mitochondrial $\mathrm{Ca}^{2+}$ Uniporter. Cell Rep. 2019, 26, 1203-1212.e1204. [CrossRef] [PubMed]

22. Kamer, K.J.; Mootha, V.K. MICU1 and MICU2 play nonredundant roles in the regulation of the mitochondrial calcium uniporter. EMBO Rep. 2014, 15, 299-307. [CrossRef] [PubMed]

23. Rizzuto, R.; Brini, M.; Murgia, M.; Pozzan, T. Microdomains with high $\mathrm{Ca}^{2+}$ close to IP3-sensitive channels that are sensed by neighboring mitochondria. Science 1993, 262, 744-747. [CrossRef] [PubMed]

24. Kornmann, B.; Currie, E.; Collins, S.R.; Schuldiner, M.; Nunnari, J.; Weissman, J.S.; Walter, P. An ER-mitochondria tethering complex revealed by a synthetic biology screen. Science 2009, 325, 477-481. [CrossRef] [PubMed]

25. de Brito, O.M.; Scorrano, L. Mitofusin 2 tethers endoplasmic reticulum to mitochondria. Nature 2008, 456, 605. [CrossRef]

26. Filadi, R.; Greotti, E.; Turacchio, G.; Luini, A.; Pozzan, T.; Pizzo, P. Presenilin 2 modulates endoplasmic reticulum-mitochondria coupling by tuning the antagonistic effect of mitofusin 2. Cell Rep. 2016, 15, 2226-2238. [CrossRef]

27. Bhosale, G.; Sharpe, J.A.; Koh, A.; Kouli, A.; Szabadkai, G.; Duchen, M.R. Pathological consequences of MICU1 mutations on mitochondrial calcium signalling and bioenergetics. Biochim. Biophys. Acta (Bba)-Mol. Cell Res. 2017, 1864, 1009-1017. [CrossRef] 
28. Logan, C.V.; Szabadkai, G.; Sharpe, J.A.; Parry, D.A.; Torelli, S.; Childs, A.-M.; Kriek, M.; Phadke, R.; Johnson, C.A.; Roberts, N.Y. Loss-of-function mutations in MICU1 cause a brain and muscle disorder linked to primary alterations in mitochondrial calcium signaling. Nat. Genet. 2014, 46, 188. [CrossRef]

29. Lewis-Smith, D.; Kamer, K.J.; Griffin, H.; Childs, A.-M.; Pysden, K.; Titov, D.; Duff, J.; Pyle, A.; Taylor, R.W.; Yu-Wai-Man, P. Homozygous deletion in MICU1 presenting with fatigue and lethargy in childhood. Neurol. Genet. 2016, 2, e59. [CrossRef]

30. Liu, J.C.; Liu, J.; Holmström, K.M.; Menazza, S.; Parks, R.J.; Fergusson, M.M.; Yu, Z.-X.; Springer, D.A.; Halsey, C.; Liu, C. MICU1 serves as a molecular gatekeeper to prevent in vivo mitochondrial calcium overload. Cell Rep. 2016, 16, 1561-1573. [CrossRef]

31. Antony, A.N.; Paillard, M.; Moffat, C.; Juskeviciute, E.; Correnti, J.; Bolon, B.; Rubin, E.; Csordás, G.; Seifert, E.L.; Hoek, J.B. MICU1 regulation of mitochondrial Ca 2+ uptake dictates survival and tissue regeneration. Nat. Commun. 2016, 7, 10955. [CrossRef] [PubMed]

32. König, T.; Tröder, S.E.; Bakka, K.; Korwitz, A.; Richter-Dennerlein, R.; Lampe, P.A.; Patron, M.; Mühlmeister, M.; Guerrero-Castillo, S.; Brandt, U. The m-AAA protease associated with neurodegeneration limits MCU activity in mitochondria. Mol. Cell 2016, 64, 148-162. [CrossRef] [PubMed]

33. Schwarz, G. Estimating the dimension of a model. Ann. Stat. 1978, 6, 461-464. [CrossRef]

34. Ullah, G.; Mak, D.-O.D.; Pearson, J.E. A data-driven model of a modal gated ion channel: The inositol 1, 4, 5-trisphosphate receptor in insect Sf9 cells. J. Gen. Physiol. 2012, 140, 159-173. [CrossRef] [PubMed]

35. Ullah, G.; Parker, I.; Mak, D.-O.D.; Pearson, J.E. Multi-scale data-driven modeling and observation of calcium puffs. Cell Calcium 2012, 52, 152-160. [CrossRef]

36. Wacquier, B.; Combettes, L.; Van Nhieu, G.T.; Dupont, G. Interplay between intracellular Ca ${ }^{2+}$ oscillations and $\mathrm{Ca}^{2+}$-stimulated mitochondrial metabolism. Sci. Rep. 2016, 6, 19316. [CrossRef]

37. Fieni, F.; Lee, S.B.; Jan, Y.N.; Kirichok, Y. Activity of the mitochondrial calcium uniporter varies greatly between tissues. Nat. Commun. 2012, 3, 1317. [CrossRef]

38. Magnus, G.; Keizer, J. Minimal model of beta-cell mitochondrial $\mathrm{Ca}^{2+}$ handling. Am. J. Physiol. Cell Physiol. 1997, 273, C717-C733. [CrossRef]

39. De Stefani, D.; Patron, M.; Rizzuto, R. Structure and function of the mitochondrial calcium uniporter complex. Biochim. Biophys. Acta (Bba)-Mol. Cell Res. 2015, 1853, 2006-2011. [CrossRef]

40. Beece, D.; Eisenstein, L.; Frauenfelder, H.; Good, D.; Marden, M.; Reinisch, L.; Reynolds, A.; Sorensen, L.; Yue, K. Solvent viscosity and protein dynamics. Biochemistry 1980, 19, 5147-5157. [CrossRef]

41. Wacquier, B.; Combettes, L.; Dupont, G. Dual dynamics of mitochondrial permeability transition pore opening. Sci. Rep. 2020, 10,1-10. [CrossRef] [PubMed]

42. Csordás, G.; Várnai, P.; Golenár, T.; Roy, S.; Purkins, G.; Schneider, T.G.; Balla, T.; Hajnóczky, G. Imaging interorganelle contacts and local calcium dynamics at the ER-mitochondrial interface. Mol. Cell 2010, 39, 121-132. [CrossRef] [PubMed]

43. Llinas, R.; Sugimori, M.; Silver, R.B. Microdomains of high calcium concentration in a presynaptic terminal. Science 1992, 256, 677-679. [CrossRef] [PubMed]

44. Mammucari, C.; Patron, M.; Granatiero, V.; Rizzuto, R. Molecules and roles of mitochondrial calcium signaling. Biofactors 2011, 37, 219-227. [CrossRef]

45. Szabadkai, G.; Bianchi, K.; Várnai, P.; De Stefani, D.; Wieckowski, M.R.; Cavagna, D.; Nagy, A.I.; Balla, T.; Rizzuto, R. Chaperone-mediated coupling of endoplasmic reticulum and mitochondrial $\mathrm{Ca}^{2+}$ channels. J. Cell Biol. 2006, 175, 901-911. [CrossRef]

46. Neher, E. Vesicle pools and Ca2+ microdomains: New tools for understanding their roles in neurotransmitter release. Neuron 1998, 20, 389-399. [CrossRef]

47. Qi, H.; Li, L.; Shuai, J. Optimal microdomain crosstalk between endoplasmic reticulum and mitochondria for $\mathrm{Ca}^{2+}$ oscillations. Sci. Rep. 2015, 5, 7984. [CrossRef]

48. Vais, H.; Foskett, J.K.; Ullah, G.; Pearson, J.E.; Mak, D.-O.D. Permeant calcium ion feed-through regulation of single inositol 1, 4, 5-trisphosphate receptor channel gating. J. Gen. Physiol. 2012, 140, 697-716. [CrossRef]

49. Allbritton, N.L.; Meyer, T.; Stryer, L. Range of messenger action of calcium ion and inositol 1, 4, 5-trisphosphate. Science 1992, 258, 1812-1815. [CrossRef]

50. Gilabert, J.A. Cytoplasmic calcium buffering. In Calcium Signaling; Springer: Berlin/Heidelberg, Germany, 2012; pp. 483-498. 
51. Calvo-Rodriguez, M.; Hou, S.S.; Snyder, A.C.; Kharitonova, E.K.; Russ, A.N.; Das, S.; Fan, Z.; Muzikansky, A.; Garcia-Alloza, M.; Serrano-Pozo, A. Increased mitochondrial calcium levels associated with neuronal death in a mouse model of Alzheimer's disease. Nat. Commun. 2020, 11, 1-17. [CrossRef]

52. Csordás, G.; Renken, C.; Várnai, P.; Walter, L.; Weaver, D.; Buttle, K.F.; Balla, T.; Mannella, C.A.; Hajnóczky, G. Structural and functional features and significance of the physical linkage between ER and mitochondria. J. Cell Biol. 2006, 174, 915-921. [CrossRef] [PubMed]

53. Wang, H.-J.; Guay, G.; Pogan, L.; Sauvé, R.; Nabi, I.R. Calcium regulates the association between mitochondria and a smooth subdomain of the endoplasmic reticulum. J. Cell Biol. 2000, 150, 1489-1498. [CrossRef] [PubMed]

54. De Brito, O.M.; Scorrano, L. An intimate liaison: Spatial organization of the endoplasmic reticulum-mitochondria relationship. EMBO J. 2010, 29, 2715-2723. [CrossRef] [PubMed]

55. Wu, P. Regulation of the activity of the pyruvate dehydrogenase complex. Adv. Enzym. Regul. 2002, 42, 249.

56. Denton, R.M. Regulation of mitochondrial dehydrogenases by calcium ions. Biochim. Biophys. Acta (Bba)-Bioenerg. 2009, 1787, 1309-1316. [CrossRef]

57. Satrustegui, J.; Pardo, B.; Del Arco, A. Mitochondrial transporters as novel targets for intracellular calcium signaling. Physiol. Rev. 2007, 87, 29-67. [CrossRef]

58. Contreras, L.; Gomez-Puertas, P.; Iijima, M.; Kobayashi, K.; Saheki, T.; Satrústegui, J. Ca ${ }^{2+}$ Activation Kinetics of the Two Aspartate-Glutamate Mitochondrial Carriers, Aralar and Citrin ROLE IN THE HEART MALATE-ASPARTATE NADH SHUTTLE. J. Biol. Chem. 2007, 282, 7098-7106. [CrossRef]

59. Bertram, R.; Pedersen, M.G.; Luciani, D.S.; Sherman, A. A simplified model for mitochondrial ATP production. J. Theor. Biol. 2006, 243, 575-586. [CrossRef]

60. Cortassa, S.; Aon, M.A.; Marbán, E.; Winslow, R.L.; O’Rourke, B. An integrated model of cardiac mitochondrial energy metabolism and calcium dynamics. Biophys. J. 2003, 84, 2734-2755. [CrossRef]

61. Toglia, P.; Cheung, K.-H.; Mak, D.-O.D.; Ullah, G. Impaired mitochondrial function due to familial Alzheimer's disease-causing presenilins mutants via $\mathrm{Ca}^{2+}$ disruptions. Cell Calcium 2016, 59, 240-250. [CrossRef]

62. Toglia, P.; Demuro, A.; Mak, D.-O.D.; Ullah, G. Data-driven modeling of mitochondrial dysfunction in Alzheimer's disease. Cell Calcium 2018, 76, 23-35. [CrossRef] [PubMed]

63. Toglia, P.; Ullah, G. The gain-of-function enhancement of IP3-receptor channel gating by familial Alzheimer's disease-linked presenilin mutants increases the open probability of mitochondrial permeability transition pore. Cell Calcium 2016, 60, 13-24. [CrossRef] [PubMed]

64. DeLuca, H.F.; Engstrom, G. Calcium uptake by rat kidney mitochondria. Proc. Natl. Acad. Sci. USA 1961, 47, 1744. [CrossRef] [PubMed]

65. Denton, R.; McCormack, J. Ca2+ transport by mammalian mitochondria and its role in hormone action. Am. J. Physiol. Endocrinol. Metab. 1985, 249, E543-E554. [CrossRef] [PubMed]

66. Wescott, A.P.; Kao, J.P.; Lederer, W.J.; Boyman, L. Voltage-energized calcium-sensitive ATP production by mitochondria. Nat. Metab. 2019, 1, 975-984. [CrossRef]

67. Nguyen, M.-H.T.; Dudycha, S.J.; Jafri, M.S. Effect of $\mathrm{Ca}^{2+}$ on cardiac mitochondrial energy production is modulated by $\mathrm{Na}^{+}$and $\mathrm{H}^{+}$dynamics. Am. J. Physiol. Cell Physiol. 2007, 292, C2004-C2020. [CrossRef]

68. Diekman, C.O.; Fall, C.P.; Lechleiter, J.D.; Terman, D. Modeling the neuroprotective role of enhanced astrocyte mitochondrial metabolism during stroke. Biophys. J. 2013, 104, 1752-1763. [CrossRef]

69. Wei, A.-C.; Aon, M.A.; O’Rourke, B.; Winslow, R.L.; Cortassa, S. Mitochondrial energetics, pH regulation, and ion dynamics: A computational-experimental approach. Biophys. J. 2011, 100, 2894-2903. [CrossRef]

70. Toglia, P.; Ullah, G. Mitochondrial dysfunction and role in spreading depolarization and seizure. J. Comput. Neurosci. 2019, 47, 91-108. [CrossRef]

71. Williams, G.S.; Boyman, L.; Chikando, A.C.; Khairallah, R.J.; Lederer, W. Mitochondrial calcium uptake. Proc. Natl. Acad. Sci. USA 2013, 110, 10479-10486. [CrossRef]

72. Wacquier, B.; Romero Campos, H.E.; González-Vélez, V.; Combettes, L.; Dupont, G. Mitochondrial Ca ${ }^{2+}$ dynamics in cells and suspensions. FEBS J. 2017, 284, 4128-4142. [CrossRef] [PubMed]

73. Jadiya, P.; Kolmetzky, D.W.; Tomar, D.; Di Meco, A.; Lombardi, A.A.; Lambert, J.P.; Luongo, T.S.; Ludtmann, M.H.; Praticò, D.; Elrod, J.W. Impaired mitochondrial calcium efflux contributes to disease progression in models of Alzheimer's disease. Nat. Commun. 2019, 10, 3885. [CrossRef] [PubMed] 
74. Raffaello, A.; De Stefani, D.; Sabbadin, D.; Teardo, E.; Merli, G.; Picard, A.; Checchetto, V.; Moro, S.; Szabò, I.; Rizzuto, R. The mitochondrial calcium uniporter is a multimer that can include a dominant-negative pore-forming subunit. EMBO J. 2013, 32, 2362-2376. [CrossRef] [PubMed]

75. Ullah, G.; Bruno, W.J.; Pearson, J.E. Simplification of reversible Markov chains by removal of states with low equilibrium occupancy. J. Theor. Biol. 2012, 311, 117-129. [CrossRef]

76. Ullah, G.; Jung, P. Modeling the statistics of elementary calcium release events. Biophys. J. 2006, 90, 3485-3495. [CrossRef] [PubMed]

77. Mak, D.-O.D.; Cheung, K.-H.; Toglia, P.; Foskett, J.K.; Ullah, G. Analyzing and quantifying the gain-of-function enhancement of IP3 receptor gating by familial Alzheimer's disease-causing mutants in Presenilins. PLoS Comput. Biol. 2015, 11, e1004529. [CrossRef]

78. Bezprozvanny, I. Calcium signaling and neurodegenerative diseases. Trends Mol. Med. 2009, 15, 89-100. [CrossRef]

79. Shah, S.I.; Paine, J.G.; Perez, C.; Ullah, G. Mitochondrial fragmentation and network architecture in degenerative diseases. PLoS ONE 2019, 14, e0223014. [CrossRef]

(C) 2020 by the authors. Licensee MDPI, Basel, Switzerland. This article is an open access article distributed under the terms and conditions of the Creative Commons Attribution (CC BY) license (http://creativecommons.org/licenses/by/4.0/). 